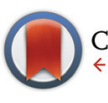

CrossMark $\leftarrow$ click for updates

Cite this: Dalton Trans., 2014, 43 14346

Received 15th May 2014, Accepted 3rd June 2014

DOI: $10.1039 / c 4 d t 01442 a$ www.rsc.org/dalton

\title{
Homo- and heteroleptic alkoxycarbene f-element complexes and their reactivity towards acidic $\mathrm{N}-\mathrm{H}$ and $\mathrm{C}-\mathrm{H}$ bondst
}

\author{
Polly L. Arnold, ${ }^{* a}$ Thomas Cadenbach, ${ }^{a}$ Isobel H. Marr, ${ }^{a}$ Andrew A. Fyfe, ${ }^{a}$ \\ Nicola L. Bell, ${ }^{a}$ Ronan Bellabarba, ${ }^{b}$ Robert P. Tooze ${ }^{b}$ and Jason B. Love*a
}

\begin{abstract}
The reactivity of a series of organometallic rare earth and actinide complexes with hemilabile NHCligands towards substrates with acidic $\mathrm{C}-\mathrm{H}$ and $\mathrm{N}-\mathrm{H}$ bonds is described. The synthesis, characterisation and $\mathrm{X}$-ray structures of the new heteroleptic mono- and bis $(\mathrm{NHC})$ cyclopentadienyl complexes $\mathrm{LnCp}_{2}(\mathrm{~L})$ $1\left(\mathrm{Ln}=\mathrm{SC}, \mathrm{Y}, \mathrm{Ce} ; \mathrm{L}=\right.$ alkoxy-tethered carbene $\left[\mathrm{OCMe}_{2} \mathrm{CH}_{2}(1-\mathrm{C}\{\mathrm{NCHCHN}\right.$ 'Pr $\left.\}]\right), \operatorname{LnCp}(\mathrm{L})_{2}(\mathrm{Ln}=\mathrm{Y}) \mathbf{2}$, and the homoleptic tetrakis $(\mathrm{NHC})$ complex $\mathrm{Th}(\mathrm{L})_{4} 4$ are described. The reactivity of these complexes, and of the homoleptic complexes $\mathrm{Ln}(\mathrm{L})_{3}(\mathrm{Ln}=\mathrm{Sc} 3, \mathrm{Ce})$, with $\mathrm{E}-\mathrm{H}$ substrates is described, where $\mathrm{EH}=$ pyrrole $\mathrm{C}_{4} \mathrm{H}_{4} \mathrm{NH}$, indole $\mathrm{C}_{8} \mathrm{H}_{6} \mathrm{NH}$, diphenylacetone $\mathrm{Ph}_{2} \mathrm{CC}(\mathrm{O}) \mathrm{Me}$, terminal alkynes $\mathrm{RC} \equiv \mathrm{CH}\left(\mathrm{R}=\mathrm{Me}_{3} \mathrm{Si}, \mathrm{Ph}\right)$, and cyclopentadiene $\mathrm{C}_{5} \mathrm{H}_{6}$. Complex 1-Y heterolytically cleaves and adds pyrrole and indole $\mathrm{N}-\mathrm{H}$ across the metal carbene bond, whereas 1-Ce does not, although 3 and $\mathbf{4}$ form $\mathrm{H}$-bonded adducts. Complexes 1-Y and 1-Sc form adducts with $\mathrm{CpH}$ without cleaving the acidic $\mathrm{C}-\mathrm{H}$ bond, 1-Ce cleaves the $\mathrm{Cp}-\mathrm{H}$ bond, but 2 reacts to form the very rare $\mathrm{H}^{+}-\left[\mathrm{C}_{5} \mathrm{H}_{5}\right]^{-}-\mathrm{H}^{+}$motif. Complex $1-\mathrm{Ce}$ cleaves alkyne $\mathrm{C}-\mathrm{H}$ bonds but the products rearrange upon formation, while complex 1-Y cleaves the $\mathrm{C}-\mathrm{H}$ bond in diphenylacetone forming a product which rearranges to the $\mathrm{Y}-\mathrm{O}$ bonded enolate product.
\end{abstract}

\section{Introduction}

N-heterocyclic carbenes (NHCs) have found widespread application in many areas of molecular chemistry, as nucleophilic reagents in organic transformations ${ }^{1-3}$ and as strongly Lewis basic $\sigma$-donor ligands in both transition metal ${ }^{4-6}$ and rareearth metal chemistry. ${ }^{7-11}$ As organocatalysts, NHCs are mainly used either due to their strong nucleophilicity, for example as initiators by the umpolung of electrophilic carbonyl groups into nucleophilic acyl anion equivalents for benzoin condensation ${ }^{12,13}$ and the Stetter reaction, ${ }^{14,15}$ or Brønsted basicity in stoichiometric and catalytic transesterification ${ }^{16-18}$ and acylation ${ }^{19-21}$ reactions. In late transition metal chemistry, NHCs are extensively exploited as ligands for homogeneous catalysts in alkene metathesis and C-C coupling reactions. ${ }^{4-6,22}$

In contrast, the use of neutral NHCs as donor-ligands for the rare earth elements is less common due to a mismatch in

\footnotetext{
${ }^{a}$ EaStCHEM School of Chemistry, University of Edinburgh, The King's Buildings, Edinburgh,EH93JJ, UK.E-mail: jason.love@ed.ac.uk, polly.arnold@ed.ac.uk ${ }^{b}$ Sasol Technology UK, Purdie Building, North Haugh, St Andrews, KY16 9SR, UK $\dagger$ Electronic supplementary information (ESI) available. CCDC 1003236-1003246. For ESI and crystallographic data in CIF or other electronic format see DOI: 10.1039/c4dt01442a
}

the bonding to the hard Lewis acid, resulting in inopportune lability of the NHC in these complexes. ${ }^{8,10,11}$ Metallocenes of the rare earth metals are known to activate $\mathrm{C}-\mathrm{H}$ bonds in both saturated and unsaturated organic substrates through $\sigma$-bond metathesis mechanisms rather than the conventional two-electron oxidative addition-reductive elimination pathway seen for late transition metals. ${ }^{23-25}$ Furthermore, organometallic complexes of f-block metals such as alkyls, hydrides, and amido compounds are excellent catalysts for the hydroamination, phosphination, alkoxylation, and silylation of alkenes. ${ }^{26-31}$

Recently, we and others became interested to combine the advantages of NHC ligands with the beneficial properties of rare earth metals. ${ }^{8,10,11}$ In order to make use of the relative lability of the NHC ligand in f-block compounds, we exploited anionic O- or N-moieties to tether these ligands to the Lewis acidic metal. Accordingly, these tethered NHC ligands can function as reactive ligands, and the combination of the Lewis acidic metal cation and nucleophilic carbene ligand has led us to compare the reactivity of these complexes to frustrated Lewis pairs. ${ }^{32,33}$ For example, we have shown that polar substrates can be cleaved heterolytically, in a reversible manner, across the metal-NHC bond. Subsequent heating of these addition products led to an elimination of the functionalised substrate from the lanthanide complex, reforming the metalcarbene bond. This reactivity allowed us to form new C-C, 
$\mathrm{C}-\mathrm{E}$, and $\mathrm{N}-\mathrm{E}(\mathrm{E}=\mathrm{Si}, \mathrm{P}, \mathrm{B}$ or $\mathrm{Sn})$ bonds at redox innocent metals. $^{34,35}$

In order to gain a deeper insight into these reactions and to broaden the substrate scope we were interested in the reactivity of electropositive metal NHC complexes towards substrates with acidic $\mathrm{C}-\mathrm{H}$ and $\mathrm{N}-\mathrm{H}$ bonds in order to avoid the incorporation of halide or pseudo-halide anions. In this context, $\mathrm{N}$-heterocycles such as those based on pyrrole and indole are of particular interest due to their widespread application in natural products, pharmaceutical agents and materials science. ${ }^{36}$ Thus, their functionalization has been subject of numerous studies. Additionally, due to their flexible binding mode, pyrrole and indole anions have found use as important ligands in transition metal and rare-earth metal chemistry. ${ }^{36-43}$ For example, it was shown that rare-earth metal complexes of functionalized indolyl ligands are catalysts for olefin polymerization. ${ }^{44}$

Herein, we describe the syntheses of heteroleptic monoand bis(NHC) cyclopentadienyl, as well as homoleptic tris- and tetrakis(NHC) f-block metal complexes and their reactivity towards $\mathrm{N}-\mathrm{H}$ and $\mathrm{C}-\mathrm{H}$ acidic substrates.

\section{Results and discussion}

\section{Syntheses of mono-, bis-, tris- and tetrakis(carbene) metal complexes}

We identified tris(cyclopentadienyl) complexes as potential synthons for mono- and bis(carbene) cyclopentadienyl rareearth complexes as the cyclopentadienyl salt should be readily eliminated. Reaction between $\mathrm{YCp}_{3}$ and one equivalent of $\mathrm{KL}$, $\mathrm{K}\left[\mathrm{OCMe}_{2} \mathrm{CH}_{2}\left(1-\mathrm{C}\left\{\mathrm{NCHCHN}^{\mathrm{i}} \mathrm{Pr}\right\}\right)\right]$, in THF at $60^{\circ} \mathrm{C}$ affords colourless crystals of $\mathrm{YCp}_{2}(\mathrm{~L}) \mathbf{1 - Y}$ in good yield (78\%) after workup (Scheme 1). Using a similar approach, the scandium and cerium compounds $\mathrm{ScCp}_{2}(\mathrm{~L})$ 1-Sc and $\mathrm{CeCp}_{2}(\mathrm{~L})$ 1-Ce were isolated. Compounds 1-Sc, 1-Y, 1-Ce were characterized fully, in particular by NMR spectroscopy and single crystal X-ray diffraction (see below). Furthermore, the reaction of $\mathrm{YCp}_{3}$ and two equivalents of $\mathrm{KL}$ allows the isolation of $\mathrm{YCp}(\mathrm{L})_{2} 2-\mathrm{Y}$ in good yield (71\%); this complex can also be prepared by the reaction of 1-Y with KL. Single crystals of 2-Y suitable for X-ray crystallography were grown from a concentrated thf solution. The mono(carbene)bis(cyclopentadienyl) compounds can also be made by salt metathesis from the corresponding bis(cyclopentadienyl) chloride complexes $\mathrm{LnCp}_{2}(\mathrm{Cl})$ and $\mathrm{KL}$ in $\mathrm{THF}$ at $60{ }^{\circ} \mathrm{C}$, but lower yields are isolated from this route; the ready availability of $\mathrm{LnCp}_{3}$ starting materials renders the former synthetic route preferable.

The NMR spectra of all compounds $\mathbf{1}$ and $\mathbf{2}$ indicate that the structures are rigid in solution at room temperature with the carbene ligands bound to the metal centres. The ${ }^{13} \mathrm{C}$ NMR spectrum of 1-Y in $\mathrm{C}_{6} \mathrm{D}_{6}$ shows a doublet at $192.1 \mathrm{ppm}$ with a coupling constant of $47.6 \mathrm{~Hz}$; complexes containing yttriumbound carbenes have chemical shifts in the range of 186-197 ppm. The ${ }^{1} \mathrm{H}$ NMR spectrum of $\mathbf{1 - Y}$ contains, as expected, a single resonance for both cyclopentadienyl ligands
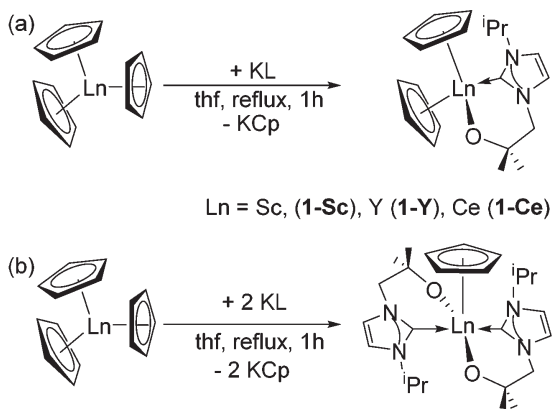
$\operatorname{Ln}=\mathrm{Y}(2-\mathrm{Y})$
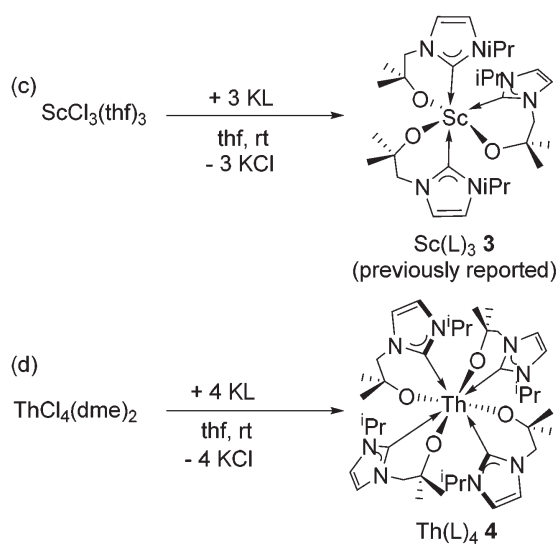

Scheme 1 Syntheses of (a) 1-Sc, 1-Y, 1-Ce and (b) 2-Y by KCp elimination, and of the complexes 3 (c, previously reported) ${ }^{32}$ and 4 (d) by salt metathesis routes.

at 6.21 ppm as well as a set of resonances for the NHC ligand. The most characteristic resonances of the alkoxy tethered carbene are defined by the two backbone protons of the imidazolium ring at $6.13\left(J_{\mathrm{HH}}=1.70\right)$ and $6.09\left(J_{\mathrm{HH}}=1.61 \mathrm{~Hz}\right)$ as well as a septet for the single isopropyl $\mathrm{H}$ at $4.18 \mathrm{ppm}\left(J_{\mathrm{HH}}=6.76 \mathrm{~Hz}\right)$.

The ${ }^{1} \mathrm{H}$ NMR spectrum of 1-Ce shows a set of paramagnetically contact-shifted ligand resonances between 20 and $-5 \mathrm{ppm}$. The ${ }^{1} \mathrm{H}$ NMR spectrum of $2-Y$ in $\mathrm{C}_{6} \mathrm{D}_{6}$ shows a single set of signals for both NHC ligands and a corresponding singlet for the cyclopentadienyl ligand at $6.53 \mathrm{ppm}$. As indicated by the higher frequency of the $\mathrm{Cp}$ resonance, the resonances due to the NHC groups are also shifted to higher frequency at 6.36 (doublet for backbone NHC protons, $J_{\mathrm{HH}}=$ $1.50 \mathrm{~Hz}$ ), 6.20 (doublet for backbone NHC protons, $J_{\mathrm{HH}}=$ $1.38 \mathrm{~Hz}$ ) and $5.73 \mathrm{ppm}$ (septet for single isopropyl proton, $J_{\mathrm{HH}}=6.77 \mathrm{~Hz}$ ). The ${ }^{13} \mathrm{C}\left\{{ }^{1} \mathrm{H}\right\}$ NMR spectrum of 2-Y contains a doublet for the yttrium-bound carbene at $194.8 \mathrm{ppm}$ with a coupling constant of ${ }^{1} J_{\mathrm{YC}}=37.3 \mathrm{~Hz}$.

We recently reported the synthesis of $\mathrm{Sc}(\mathrm{L})_{3} 3$ (Scheme 1), ${ }^{32}$ and now show that $\mathrm{Th}(\mathrm{L})_{4} \mathbf{4}$, can be isolated from a similar room-temperature reaction between $\mathrm{ThCl}_{4}(\mathrm{dme})_{2}$ and four equivalents of KL in THF for one hour. The ${ }^{1} \mathrm{H}$ NMR spectrum of 4 shows broad resonances for all of the ligand protons at room temperature, indicative of a dynamic process occurring in solution. Two sharper resonances at 6.53 and $6.38 \mathrm{ppm}$ are identified as the imidazole $\mathrm{CH}$ groups but the isopropyl $\mathrm{CH}$ is a very broad singlet at $6.02 \mathrm{ppm}$ (Fig. 1). At $50{ }^{\circ} \mathrm{C}$, the ${ }^{1} \mathrm{H}$ NMR 


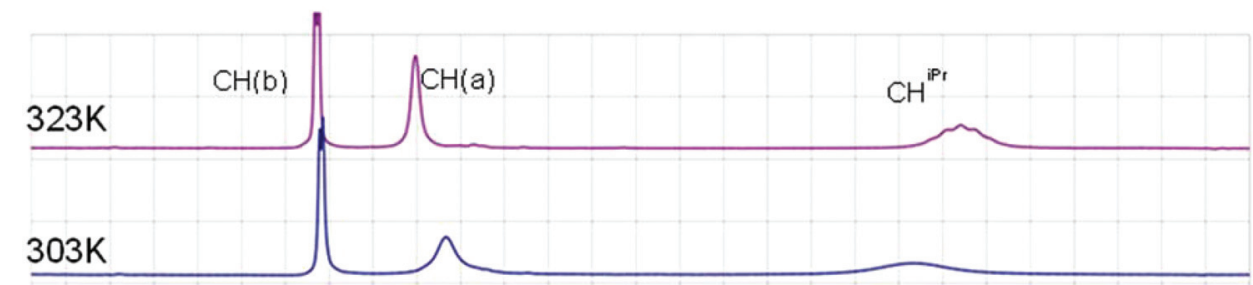

.
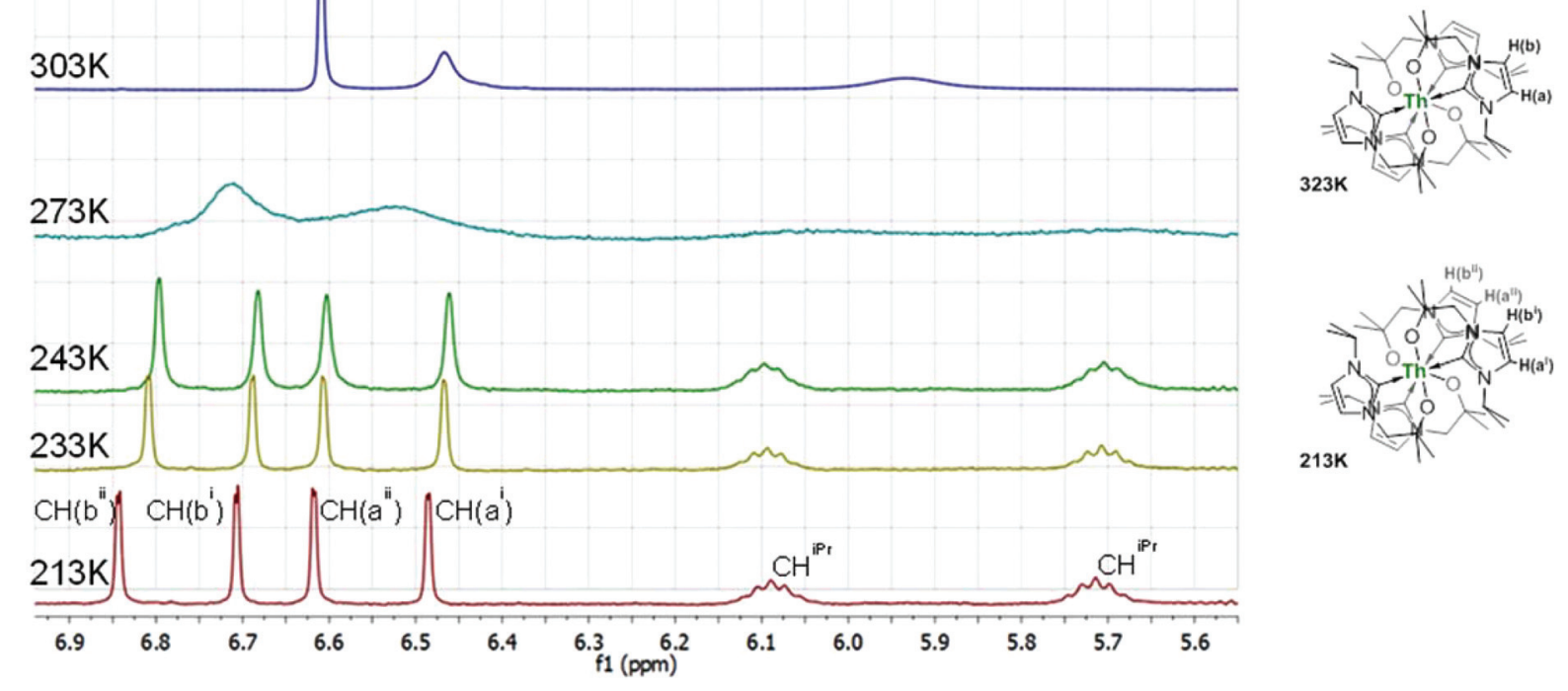

Fig. 1 Variable temperature NMR spectra for Th(L) 4 in $\mathrm{C}_{6} \mathrm{D}_{6}-\mathrm{THF}$ (range 5.5-7.3 ppm) showing the non-equivalence of the ligands at low temperature (diastereotopic $\mathrm{CH}_{2}$ groups are not displayed).

spectrum shows a significant sharpening of the ligand resonances with the septet of the isopropyl methine proton now clearly visible at $5.88 \mathrm{ppm}$ along with a singlet $(2 \mathrm{H})$ at $3.81 \mathrm{ppm}$. On cooling, the ${ }^{1} \mathrm{H}$ NMR spectra display coalescence, with, at $-60^{\circ} \mathrm{C}$, two ligand environments present in a $1: 1$ ratio with equal-intensity resonances at $6.85,6.71,6.62$ and $6.49 \mathrm{ppm}$ for the imidazole $\mathrm{CH}$ protons, and two isopropyl septet resonances clearly visible at 6.09 and $5.71 \mathrm{ppm}$. The methylene protons from the alkoxide tether now appear as four doublets integrating for $1 \mathrm{H}$ each; although one of these latter resonances is obscured by the thf co-solvent its presence can be inferred, while the others appear at 4.79, 3.19 and $3.03 \mathrm{ppm}$. The two similar ligand environments, each with diastereotopic $\mathrm{CH}_{2}$ groups are most sensibly assignable to a static, eight-coordinate structure. In this structure, the carbenes are bound to the Th centre with two magnetically non-equivalent, bidentate ligand environments (arising from slight twisting of each ligand), and diastereotopic $\mathrm{CH}_{2}$ groups in each that give rise to four nonequivalent $\mathrm{CH}$ resonances. This assignment of the low-temperature limiting solution structure of $\mathbf{4}$ is supported by its X-ray crystal structure (see below).

X-ray single crystal structures of mono-, bis-, tris and tetrakis(carbene) metal complexes

Compounds 1-Sc and 1-Y share the same structural motif in the solid state (Fig. 2 and Table 1), displaying monomeric structures in which the metal centres are coordinated in a pseudo-tetrahedral environment by two cyclopentadienyl ligands and the alkoxide and carbene donors of the bidentate NHC ligand. Crystallization of 1-Ce from a concentrated thf solution affords crystals of 1-Ce-THF, in which a molecule of THF is bound to the f-element centre and generates a distorted
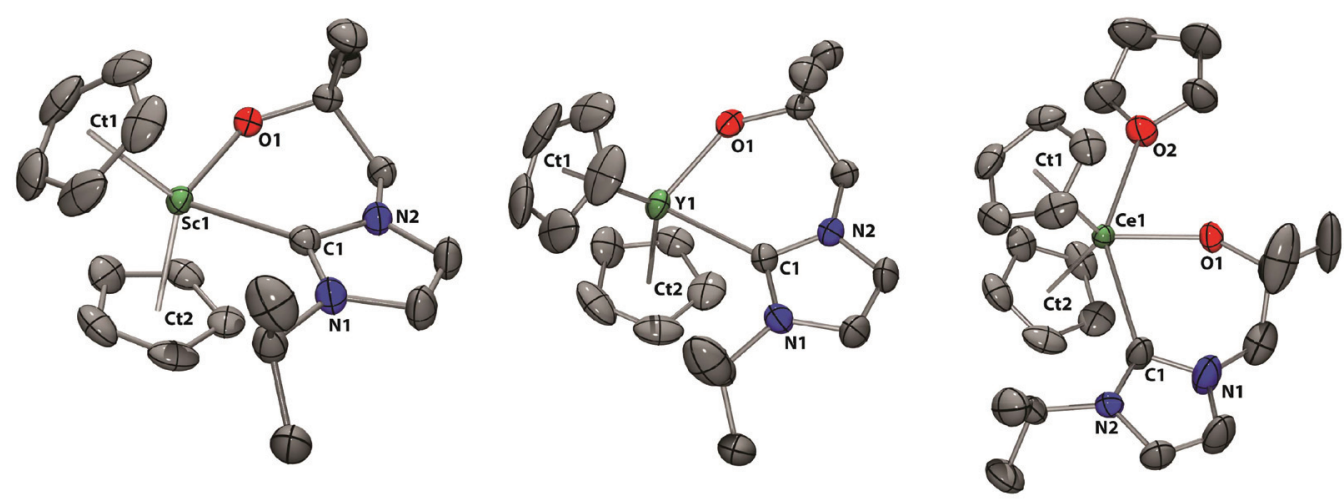

Fig. 2 Solid state structures of 1-Sc, 1-Y, 1-Ce. For clarity, $\mathrm{H}$ atoms are omitted (displacement ellipsoids drawn at 50\% probability). 
Table 1 Comparison of bond distances (Å) and angles $\left(^{\circ}\right)$ in 1-Sc, 1-Y, 1-Ce and 2-Y

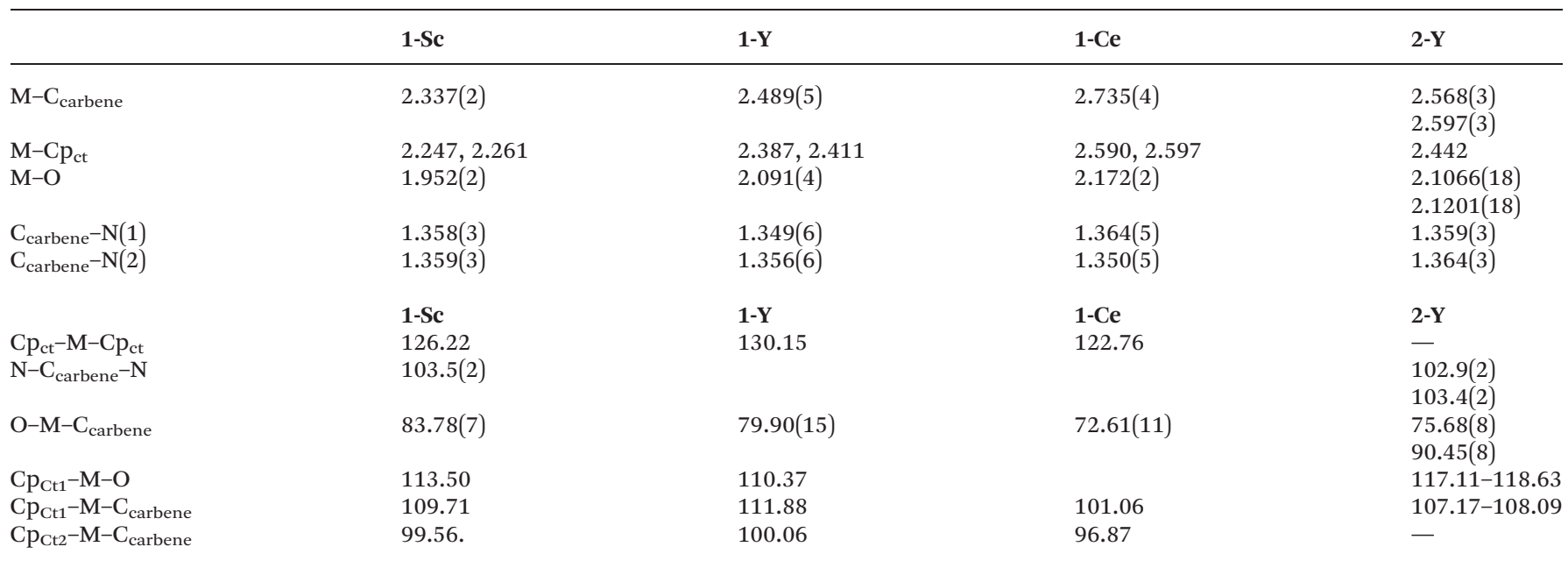

pseudo-trigonal bipyramidal coordination geometry with the bidentate NHC ligand and one $\mathrm{Cp}$ defining the equatorial plane. In all of these complexes, the cyclopentadienyl ligands are $\eta^{5}$ coordinated with $\mathrm{M}-\mathrm{Cp}$ bond distances in the expected range. Within the series of bis(cyclopentadienyl) complexes 1-Sc, 1-Y and 1-Ce, the $\mathrm{M}-\mathrm{Cp}_{\mathrm{Ct}}\left(\mathrm{Cp}_{\mathrm{Ct}}=\mathrm{Cp}\right.$ ring centroid $), \mathrm{M}-\mathrm{O}$ and $\mathrm{M}-\mathrm{C}_{\text {carbene }}$ bond distances increase in the order $\mathrm{Sc}<\mathrm{Y}<\mathrm{Ce}$, due to the increasing ionic radii and electropositive character of the corresponding metal centre. The $\mathrm{M}-\mathrm{C}_{\text {carbene }}$ bond distances in 1-Sc and 1-Y of 2.337(2) and 2.489(5) $\AA$, respectively, are noticeably shorter than those found in the homoleptic complexes $\mathrm{Sc}(\mathrm{L})_{3}{ }^{32}$ (mean $\mathrm{Sc}-\mathrm{C}_{\text {carbene }} 2.422 \AA$ ) and $\mathrm{Y}(\mathrm{L})_{3}{ }^{45}$ (mean $\mathrm{Y}^{-} \mathrm{C}_{\text {carbene }} 2.588(12) \AA$ ) and are generally short, but still comparable with other Sc-NHC and Y-NHC complexes. For example, these distances in $\mathrm{Ln}\left(\mathrm{CH}_{2} \mathrm{SiMe}_{3}\right)_{2}\left(\mathrm{Ind}-\mathrm{CH}_{2} \mathrm{CH}_{2}\{1\right.$-C(NCHCHNMes) $\})$ (Ind = indenyl) are 2.350(3) $\AA(\mathrm{Ln}=\mathrm{Sc})$ and 2.502(1) $\AA(\mathrm{Ln}=\mathrm{Y}) .{ }^{46}$ However, it should be noted that, to our knowledge, the $\mathrm{Y}-\mathrm{C}$ bond of 2.489(5) $\AA$ in $1-\mathrm{Y}$ is the shortest $\mathrm{Y}-\mathrm{NHC}$ distance yet reported. Similarly, the $\mathrm{M}-\mathrm{O}$ bonds in 1-Sc and 1-Y of 1.952(2) and 2.091(4) A, respectively, are slightly shorter compared to those found in the homoleptic complexes $\mathrm{Sc}(\mathrm{L})_{3}(\mathrm{Sc}-\mathrm{O} 1.989(2)-2.046(2) \AA)$ and $\mathrm{Y}(\mathrm{L})_{3}{ }^{45}$ (Y-O 2.115(3)2.179(7) ̊). ${ }^{32}$

The Ce- $\mathrm{C}_{\text {carbene }}$ bond length in 1-Ce of 2.735(4) $\mathrm{A}$ is slightly longer than in $\mathrm{Ce}\left(\mathrm{N}\left\{\mathrm{SiMe}_{3}\right\}_{2}\right)_{2}\left(\mathrm{C}\left\{\mathrm{N}\left({ }^{t} \mathrm{Bu}\right) \mathrm{CHCHN}\right\}-\mathrm{CH}_{2} \mathrm{CH}_{2} \mathrm{~N}^{t} \mathrm{Bu}\right)^{47}$ and similar to those in the $\mathrm{Ce}^{\mathrm{IV}}$ complex $\mathrm{Ce}(\mathrm{L})_{4}{ }^{48}$ (mean Ce- $\left.\mathrm{C}_{\text {carbene }} 2.674(7) \AA\right)$. The slightly elongated $\mathrm{Ce}-\mathrm{C}_{\text {carbene }}$ distance can be explained by the coordination of a THF molecule and the resulting steric crowding in five coordinate 1-Ce compared to the four coordinate amidocarbene complex.

Compound 2-Y crystallized with two independent molecules in the asymmetric unit; since both have very similar geometrical parameters, only one is discussed here (Fig. 3). The yttrium centre in compound 2-Y is in a distorted trigonal bipyramidal coordination environment with both alkoxides and the cyclopentadienyl group in the equatorial plane and the carbene donors axial. The $\mathrm{Y}_{-} \mathrm{C}_{\text {carbene }}$ bond lengths are 2.568(3) to 2.597(3) $\AA$ with a mean distance of $2.582 \AA$. Comparison of 2-Y with 1-Y

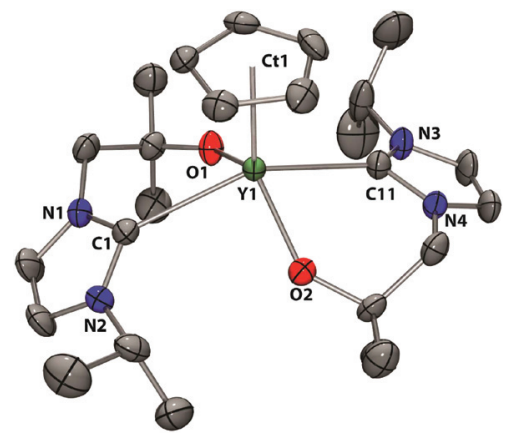

Fig. 3 Solid state structure of 2-Y. For clarity, $\mathrm{H}$ atoms are omitted (displacement ellipsoids drawn at $50 \%$ probability).

shows that the $\mathrm{Y}-\mathrm{C}_{\text {carbene }}$ as well as the $\mathrm{Y}-\mathrm{O}$ (mean 2112(4) $\AA$ ) bond distances in 2-Y are longer and now very similar to those found in $\mathrm{Y}(\mathrm{L})_{3}$. The shorter $\mathrm{M}-\mathrm{C}_{\text {carbene }}$ and $\mathrm{M}-\mathrm{O}$ distances in 1-Sc and 1-Y can be attributed to the more electrophilic character of the metal centres due to the weaker electron donating ability of the Cp rings in 1-Sc and 1-Y compared to the alkoxide groups in the homoleptic compounds $\operatorname{Sc}(\mathrm{L})_{3}$ and $\mathrm{Y}(\mathrm{L})_{3}$. Accordingly, replacement of one cyclopentadienyl ligand in 1-Y by one bidentate NHC ligand leads to the elongation of the $\mathrm{Y}-\mathrm{O}$ and $\mathrm{Y}_{-} \mathrm{C}_{\text {carbene }}$ distances in 2-Y (Fig. 2 and 3).

The solid-state structure of $\mathrm{Th}(\mathrm{L})_{4}$ (Fig. 4) shows four bidentate ligands coordinated in a mutually head-to-tail fashion, forming a square-antiprismatic Th coordination sphere. This contrasts with the solid state structures of $\mathrm{Ce}(\mathrm{L})_{4}$ and $\mathrm{U}(\mathrm{L})_{4}$ which exhibit 6 and 7-coordinate geometries respectively reflecting the large ionic radius of Th(Iv) at $119 \mathrm{pm}$ ( $c f$. Ce(Iv) $111 \mathrm{pm}$ and U(Iv) $114 \mathrm{pm}){ }^{48,49}$ The slight twist in ligand backbone affords two slightly different ligand geometries, which are reflected by the torsion angles of $25.1^{\circ}$ for O3-Th-C3-N3 and $-20.4^{\circ}$ for $\mathrm{O} 2-\mathrm{Th}-\mathrm{C} 2-\mathrm{N} 2$. However, the difference between the two ligand environments is not sufficient to be manifested in different bond distances between the two forms, within standard uncertainties. The Th-C bonds are in the 


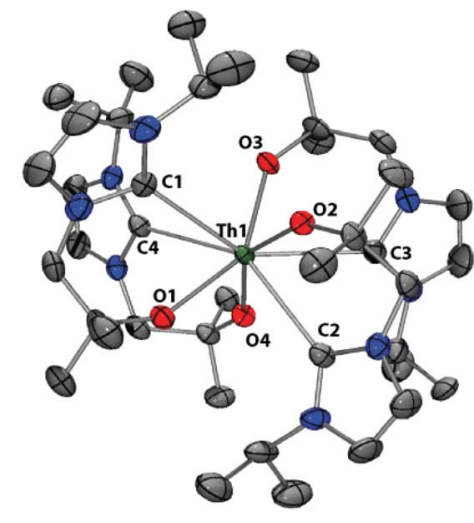

Fig. 4 Solid state structure of 4 . For clarity, $\mathrm{H}$ atoms are omitted (displacement ellipsoids drawn at $50 \%$ probability).

range $2.852(6)$ to $2.884(5) \AA$, all significantly longer than the longest direct Th-C bond yet reported of $2.77 \AA$, and reflect the weakness of the carbene-actinide interaction. The Th-O bonds are all slightly shorter than the average thorium alkoxide/aryloxide bond (2.422 $\mathrm{A}$ ) but within the expected range (2.1-2.7 $\mathrm{\AA}$ ).

\section{Reactivity}

The reactivity of the series of homoleptic and heteroleptic complexes described above was studied with range of substrates that contain acidic $\mathrm{C}-\mathrm{H}$ and $\mathrm{N}-\mathrm{H}$ bonds.

\section{N-H acidic substrates - pyrrole and indole}

The reactions between heteroleptic and homoleptic carbene complexes 1-M, 2-Y, 3 and $\mathbf{4}$ and pyrrole or indole were carried out (Scheme 2). Reaction of a solution of $\mathbf{1 - Y}$ with 1 equivalent
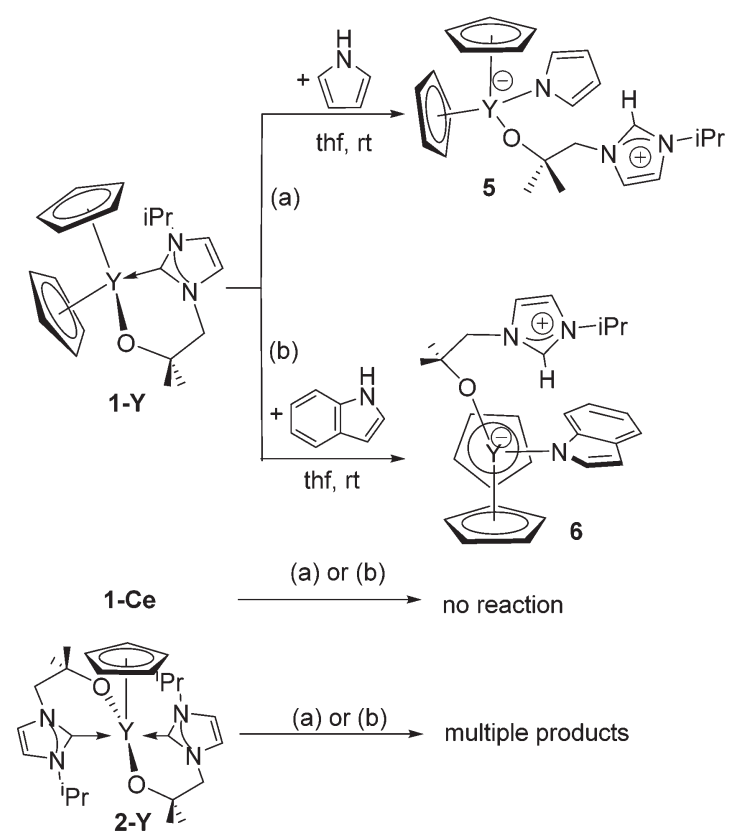

Scheme 2 Reaction of 1-Y and 2-Y with (a) pyrrole and (b) indole. of pyrrole or indole in benzene or thf at room temperature immediately results in the formation of a colourless precipitate. In each case, the complexes formulated as $\mathrm{Cp}_{2} \mathrm{Y}[\mathrm{H}\{\mathrm{C}$ $\left.\left.\left({ }^{\mathrm{i}} \mathrm{PrNCH}_{2} \mathrm{CH}_{2} \mathrm{~N}\right)\right\} \mathrm{CH}_{2} \mathrm{CMe}_{2} \mathrm{O}\right]-\left(\mathrm{L}^{\prime}\right)\left(\mathrm{L}^{\prime}=\mathrm{C}_{4} \mathrm{H}_{4} \mathrm{~N}\right.$ for 5 and $\mathrm{C}_{8} \mathrm{H}_{6} \mathrm{~N}$ for 6) are isolated in good yield. This reaction can formally be seen as an acid-base reaction in which the NHC ligand acts as a base by deprotonating the acidic $\mathrm{N}-\mathrm{H}$ of the pyrrole $\left(\mathrm{p} K_{\mathrm{a}}=\right.$ 23.0 in dmso $)^{50}$ or indole $\left(\mathrm{p} K_{\mathrm{a}}=21.0\right.$ in dmso $),{ }^{50}$ resulting in a pendant imidazolium group. The resulting nucleophilic pyrrolide and indolide anions are then trapped at the Lewis acidic yttrium centre forming the corresponding compounds 5 and $\mathbf{6}$. This reaction can also be described as the heterolytic addition of the polar $\mathrm{N}-\mathrm{H}$ substrates pyrrole and indole across the $\mathrm{Y}-\mathrm{C}_{\text {carbene }}$ bond, forming a strong $\mathrm{Y}-\mathrm{N}$ bond and an imidazolium cation. The resulting zwitterionic compounds are stable even at elevated temperatures. No reaction between $N$-methylindole and 1-Y was observed, which rules out the possibility of a $\mathrm{C}-\mathrm{H}$ bond cleavage reaction at the $\mathrm{C} 3$ position of indole followed by a subsequent rearrangement to yield 6 .

Complexes $\mathbf{5}$ and $\mathbf{6}$ are insoluble in non-polar solvents such as hexane, benzene or toluene and slightly soluble in polar solvents such as thf, dioxane and pyridine. However, it should be noted that compounds $\mathbf{5}$ and $\mathbf{6}$ decompose slowly in pyridine solutions. Moreover, both compounds are extremely reactive towards water, liberating free pyrrole and indole upon reaction. The ${ }^{1} \mathrm{H}$ NMR spectrum of 5 in $\mathrm{d}^{8}$-thf contains a single resonance for both cyclopentadienyl ligands at $5.89 \mathrm{ppm}$. The characteristic resonance for the imidazolium proton is present at $6.32 \mathrm{ppm}$ whereas the other resonances of the alkoxide arm are slightly shifted when compared to the starting material 1-Y. The pyrrolide group shows resonances at 6.86 and 5.89 ppm. Similarly, the ${ }^{1} \mathrm{H}$ NMR spectrum of 6 in $\mathrm{d}^{8}$-thf shows a single resonance for both cyclopentadienyl ligands at $5.92 \mathrm{ppm}$. The signal for the imidazolium proton is significantly shifted to higher frequency at $7.37 \mathrm{ppm}$. Furthermore, the characteristic septet for the isopropyl proton of the alkoxytethered carbene at $3.24 \mathrm{ppm}$ is shifted to lower frequency when compared to $\mathbf{1 - Y}(\delta=4.54 \mathrm{ppm})$ and $5(\delta=4.46 \mathrm{ppm})$, respectively.

Surprisingly, when a thf solution of the cerium analogue 1-Ce is mixed with pyrrole or indole, no reaction occurs. Moreover, reaction of pyrrole and indole with the bis(carbene) 2-Y leads to unidentifiable multiple products in both cases as evidenced by ${ }^{1} \mathrm{H}$ NMR spectroscopy. All attempts to drive the reaction towards one specific product by variation of reaction conditions such as time, temperature, rate of addition, and reagent concentration leads to same result, i.e. formation of multiple reaction products.

The reaction of 3 with one equivalent of pyrrole results in the formation of the pyrrole adduct $\mathrm{Sc}(\mathrm{L})_{3} \cdot \mathrm{HNC}_{4} \mathrm{H}_{4} \quad 7$ (Scheme 3), in which the pyrrole $\mathrm{N}-\mathrm{H}$ hydrogen bonds with one alkoxide tether. The ${ }^{1} \mathrm{H}$ NMR of 7 in $\mathrm{C}_{6} \mathrm{D}_{6}$ shows one set of broad resonances for all three carbene ligands. Additionally, the spectrum contains a characteristic resonance for the pyrrole $\mathrm{N}-\mathrm{H}$ at $11.61 \mathrm{ppm}$, which is shifted to higher frequency by $4.6 \mathrm{ppm}$ from the chemical shift of free pyrrole, indicative 

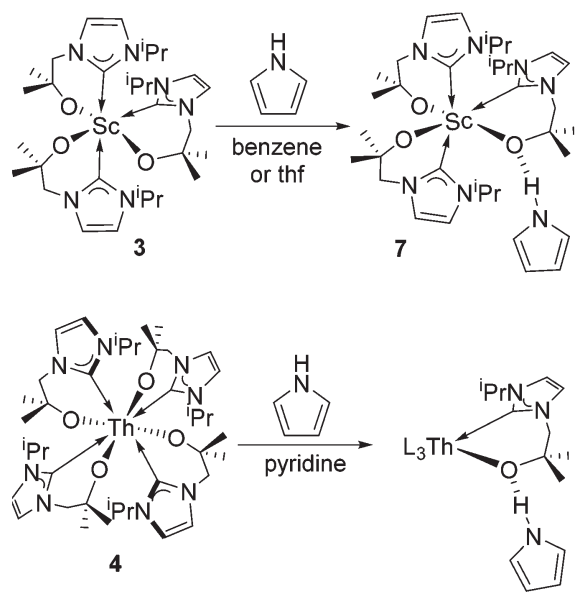

Suggested Adduct Formation

Scheme 3 Reactions of 3 and 4 with pyrrole.

of a strong hydrogen-bonding interaction. The ortho-C-H resonances are also shifted by $0.4 \mathrm{ppm}$. Furthermore, the ${ }^{13} \mathrm{C}$ NMR spectrum contains a single peak at $\delta=194.7 \mathrm{ppm}$ indicating that the scandium-carbene bonds are intact. It should be noted that removal of the solvent and drying the resulting crude material under vacuum leads to the loss of pyrrole and to the reformation of 3 .

Treatment of a pyridine solution of the homoleptic Th complex 4 with one equivalent of pyrrole results in a broadening of the ligand resonances for $\mathbf{4}$ although no distinct new species was observed. The ${ }^{1} \mathrm{H}$ NMR in $\mathrm{d}^{5}$-pyridine contains a characteristic resonance for the pyrrole $\mathrm{N}-\mathrm{H}$ at $10.18 \mathrm{ppm}$, which is shifted to higher frequency from free pyrrole, suggesting that a similar hydrogen bonding interaction to that in 7 is occurring. Also, the ortho- $\mathrm{C}-\mathrm{H}$ resonances are shifted by $0.24 \mathrm{ppm}$ and the backbone $\mathrm{C}-\mathrm{H}$ resonances are shifted by $0.14 \mathrm{ppm}$. Treatment of the reaction mixture with a further excess of pyrrole results in the sharpening of the ligand resonances and disappearance of the resonances of 4 . At least two ligand environments are evident in the ${ }^{1} \mathrm{H}$ NMR spectrum with two septets corresponding to the isopropyl CHs at $4.50 \mathrm{ppm}$ and $4.42 \mathrm{ppm}$. Based on the integration of these multiplets it appears there are at least two different species in solution. Removal of the solvent and pyrrole under reduced pressure results in the reformation of $\mathbf{4}$ suggesting that while an interaction with pyrrole occurs, it is not stable towards loss of pyrrole and supports a structure in which only hydrogenbonding interactions between the Th-alkoxide and the pyrrole $\mathrm{N}-\mathrm{H}$ occur.

Single crystals of 5, 6, and 7 were grown and the solid state structures determined by X-ray diffraction (Fig. 5 and 6). Each metal centre in 5 and $\mathbf{6}$ is four-coordinate with two $\eta^{5}$-cyclopentadienyl ligands, the protonated alkoxy-tethered $\mathrm{NHC}$ ligand and a $\kappa^{1}-\mathrm{N}-\mathrm{C}_{4} \mathrm{H}_{4} \mathrm{~N}$ (5) or $\kappa^{1}-\mathrm{N}-\mathrm{C}_{8} \mathrm{H}_{6} \mathrm{~N}$ (6) ligand. The coordination environment in each complex displays a slightly distorted tetrahedral geometry with average tetrahedral angles of $108.6^{\circ}$ for 5 and $108.8^{\circ}$ for $\mathbf{6}$. The $\mathrm{Y}-\mathrm{N}$ bond distance for the

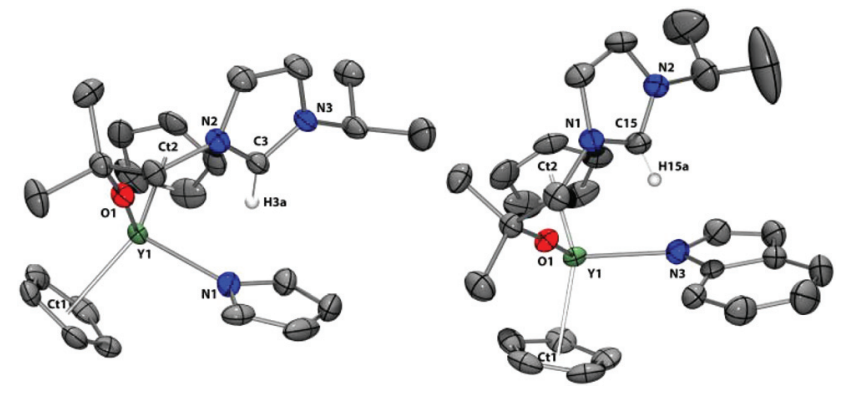

Fig. 5 Solid state structures of $\mathbf{5}$ and $\mathbf{6}$. For clarity, $\mathrm{H}$ atoms, except the imidazolium proton, are omitted (displacement ellipsoids drawn at 50\% probability).

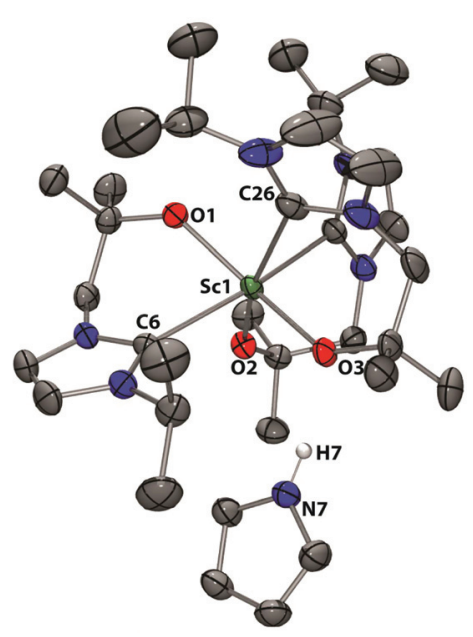

Fig. 6 Solid state structure of 7. For clarity, $\mathrm{H}$ atoms, except the pyrrole proton, are omitted (displacement ellipsoids drawn at $50 \%$ probability).

pyrrolide ligand in 5 is 2.3611(19) Å whereas the Y-N bond distance for the indolide ligand in 6 is 2.376(3) $\AA$. These values are within the expected range for $\mathrm{Y}-\mathrm{N}$ bond lengths such as $2.337(2) \quad \AA \quad$ in $\left[\mathrm{Y}\left(\eta^{5}: \eta^{1}-\mathrm{C}_{5} \mathrm{Me}_{4} \mathrm{SiMe}_{2} \mathrm{NCMe}_{3}\right)\left(\kappa^{1}-\mathrm{N}-\mathrm{C}_{4} \mathrm{H}_{4} \mathrm{~N}\right)-\right.$ (dme)]. ${ }^{51}$ The $\mathrm{Y}-\mathrm{Cp}_{\mathrm{Ct}}$ distances in $\mathbf{5}$ and $\mathbf{6}$ remain unchanged when compared to the starting compound 1-Y. As indicated by the corresponding ${ }^{1} \mathrm{H}$ NMR spectra, the carbene ligands in 5 and $\mathbf{6}$ are protonated with the resulting imidazolium protons directed towards the electron-rich, anionic nitrogen donor, so forming internal hydrogen-bonding interactions (5: C3 $\cdots \mathrm{N} 1=$

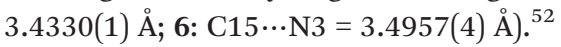

The Sc centre in 7 is coordinated by three bidentate, alkoxytethered carbene ligands in a pseudo-octahedral environment, adopting a mer geometry. The mean $\mathrm{Sc}-\mathrm{C}_{\text {carbene }}$ bond distance is $2.423 \AA$ with a range of 2.4094(14) $\AA$ to 2.4509(15) $\AA$ and thus almost identical to those observed in the parent compound 3 and comparable to those found in other ScNHC complexes, e.g. in $\mathrm{Sc}\left(\mathrm{CH}_{2} \mathrm{SiMe}_{3}\right)\left(\mathrm{L}^{\mathrm{D}}\right)_{2}$ (where $\mathrm{L}^{\mathrm{D}}=$ $\left.\left(\left\{\mathrm{C}\left(\mathrm{NDippCH}_{2} \mathrm{CH}_{2} \mathrm{~N}\right)\right\}-\mathrm{CH}_{2} \mathrm{CMe}_{2} \mathrm{O}\right)\right) .{ }^{35}$ Similarly, the Sc1-C26 bond of 2.4509(15) $\AA$ between the metal and the NHC trans to the alkoxide is notably longer than the other two $\mathrm{Sc}-\mathrm{C}_{\text {carbene }}$ bond distances of 2.4099(14) and 2.4094(14) A. The most 
striking feature in the solid state structure of 7 is the pyrrole group which hydrogen bonds through its $\mathrm{N}-\mathrm{H}$ proton to the alkoxide tether O3. The N7...O3 separation is 2.7653(16) $\AA$ and thus comparable with other complexes containing pyrrole hydrogen-bond interactions.

\section{Acidic C-H bonds - alkynes}

In order to test the reactivity of this series of homo- and heteroleptic metal carbene complexes towards acidic $\mathrm{C}-\mathrm{H}$ bonds, reactions were carried out with various alkynes $\mathrm{RC} \equiv \mathrm{CH}$ (with $\left.\mathrm{R}=\mathrm{Me}_{3} \mathrm{Si}, \mathrm{Ph},{ }^{t} \mathrm{Bu}\right)$. The $\mathrm{p} K_{\mathrm{a}}$ values of these $\mathrm{C}-\mathrm{H}$ bonds in these alkynes are in the range $25-29$, with a precise value of 28.8 reported for $\mathrm{R}=\mathrm{Ph}$ in dmso. ${ }^{53}$ None of the homoleptic alkoxy-carbene complexes $3,4, \mathrm{Ce}(\mathrm{L})_{3}{ }^{48}$ or the potassium salt KL showed any evidence of reaction; nor did the heteroleptic carbene complexes 1-Sc, 1-Y and 2-Y.

However, the reaction of a thf or benzene solution of 1-Ce with one equivalent of a terminal alkyne $\mathrm{RC} \equiv \mathrm{CH}\left(\mathrm{R}=\mathrm{Me}_{3} \mathrm{Si}\right.$, $\mathrm{Ph}$ ) at room temperature resulted in a colour change from pale yellow to dark red, followed by a rapid formation of large colourless crystals which were characterised as $\operatorname{CeCp}_{3}(\mathrm{LH}) \mathbf{8 a}$ (Scheme 4). This product presumably arises from ligand redistribution within the initially formed product, tentatively assigned as $\mathrm{CeCp}_{2}(\mathrm{HL})(\mathrm{C} \equiv \mathrm{CR}) \mathbf{8}$, which rearranges to the sterically protected and highly crystalline 8a and the alkynide $\mathrm{CeCp}(\mathrm{HL})(\mathrm{C} \equiv \mathrm{CR})_{2} \mathbf{8 b}$, which presumably oligomerises or polymerises to an insoluble material due to the high degree of steric unsaturation. The solubility of $\mathbf{8 a}$ is poor in organic solvents, and although a set of broadened, paramagnetically contact-shifted resonances can be assigned in its ${ }^{1} \mathrm{H}$ NMR spectrum, no definitive identification of the imidazolium $\mathrm{CH}$ resonance is possible. A few different reaction conditions were carried out in order to attempt to isolate the by-product $\mathbf{8 b}$ or to characterise it in situ by NMR or FTIR spectroscopy, but all were unsuccessful. To our knowledge, no kinetically inert $\sigma$-bonded cerium alkynide complexes have yet been reported. Single crystals of $\mathbf{8 a}$ were analysed by X-ray diffraction, further confirming its identity (see below, Fig. 7).

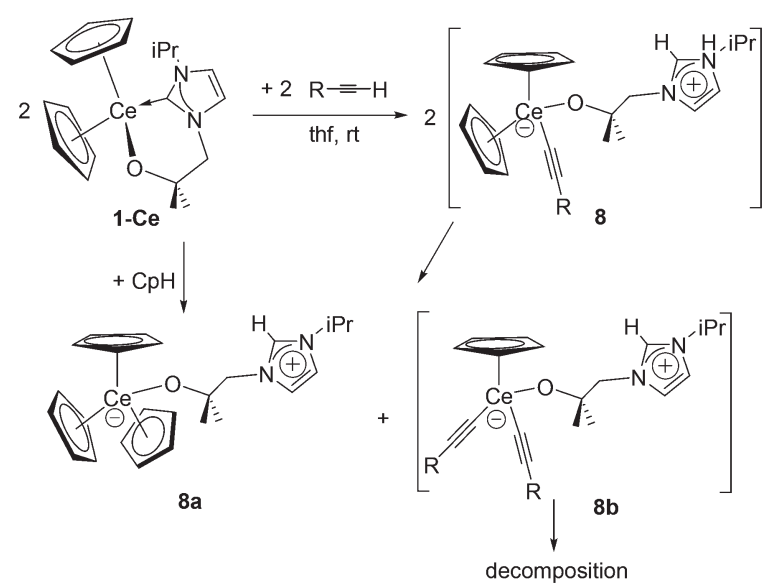

Scheme 4 Reaction of 1-Ce with alkynes $\mathrm{RC} \equiv \mathrm{CH}\left(\mathrm{R}=\mathrm{Me}_{3} \mathrm{Si}, \mathrm{Ph}\right)$.

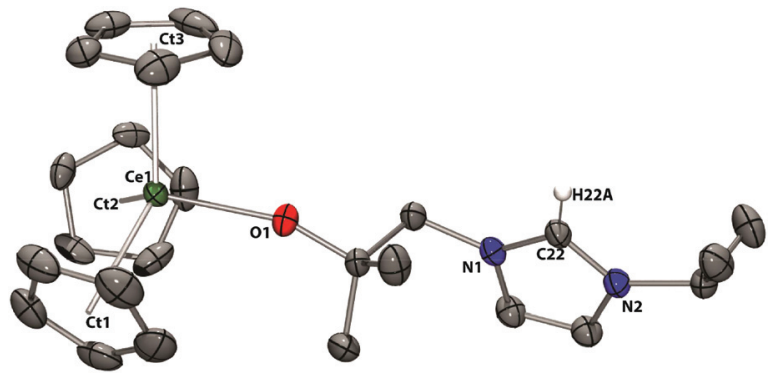

Fig. 7 Solid state structure of 8 a. For clarity, $\mathrm{H}$ atoms, except the imidazolium proton, are omitted (displacement ellipsoids drawn at $50 \%$ probability).

\section{Acidic C-H bonds - cyclopentadiene}

The reaction of 1-Ce with one equivalent of freshly distilled cyclopentadiene results in the clean formation of $\mathbf{8 a}$ in good yield (Scheme 4). This demonstrates the reactive, non-innocent character of the carbene ligand which acts as a base in order to activate the $\mathrm{C}-\mathrm{H}$ acidic substrate cyclopentadiene $\left(\mathrm{p} K_{\mathrm{a}} \mathrm{CpH}\right.$ $=18.0) .{ }^{54}$ On the other hand, monitoring a reaction between either 1-Y or 1-Sc and freshly distilled cyclopentadiene in benzene or thf solution by ${ }^{1} \mathrm{H}$ NMR spectroscopy shows that these congeners do not react to give the yttrium or scandium analogues, i.e. $\mathrm{Cp}_{3} \mathrm{Y}(\mathrm{HL})$ or $\mathrm{Cp}_{3} \mathrm{Sc}(\mathrm{HL})$, respectively. This might be a consequence of the smaller size of these two cations compared with Ce. However, it is of interest to note that after heating the mixture of $\mathbf{1 - Y}$ and cyclopentadiene for five days at $60{ }^{\circ} \mathrm{C}$, both reactants were completely unchanged, i.e. the anticipated dimerization of cyclopentadiene to dicyclopentadiene had not occurred. This suggests that perhaps there is indeed an addition reaction taking place with cyclopentadiene but it is in a rapid equilibrium in solution, resulting in no net product formation but no substrate 'decomposition'.

The reaction between $\mathbf{2 - Y}$ and two equivalents of freshly distilled cyclopentadiene at $60{ }^{\circ} \mathrm{C}$ for one hour results in the deprotonation of both cyclopentadiene molecules and in the formation of the polymer $\left[\mathrm{YCp}_{2}(\mathrm{LH})_{2}(\mathrm{Cp})\right]_{\infty} \mathbf{9}$ (Scheme 5). Analogous in part to the reaction of 1-Ce with $\mathrm{CpH}$, here both

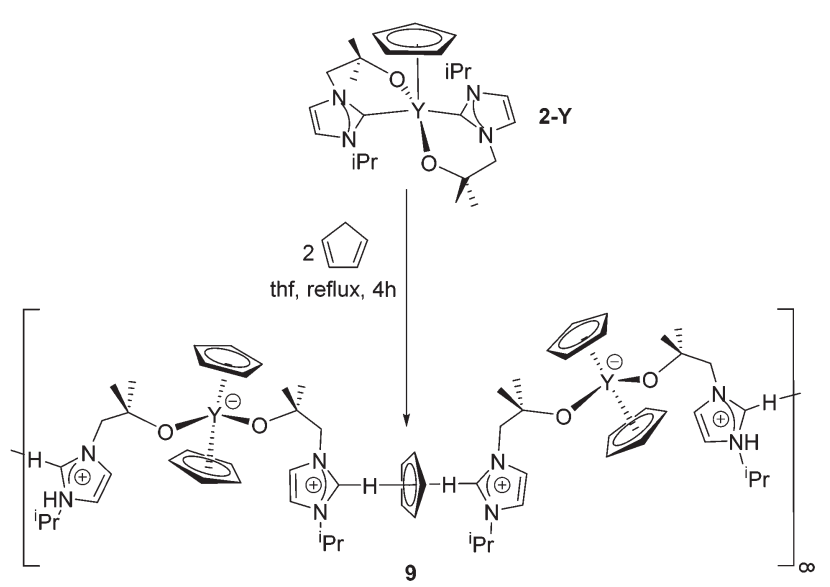

Scheme 5 Reaction of 2-Y with cyclopentadiene. 
cyclopentadiene molecules are deprotonated by the basic NHC ligands resulting in two cyclopentadienyl and two imidazolium groups. One of the cyclopentadienyl ligands is trapped at the metal centre leading to two $\eta^{5}$-cyclopentadienyl ligands and two pendant imidazolium groups at the yttrium centre in a slightly distorted tetrahedral environment (average angle is $\left.109.1^{\circ}\right)$. Most interestingly, the second cyclopentadienyl unit is subsequently entrapped by two imidazolium fragments, bonding from a neighbouring molecule through $\mathrm{C}_{\text {carbene }}-\mathrm{H} \cdots$ $(\pi$-Cp) hydrogen bonds, giving rise to a polymeric chain (Scheme 5). Interestingly, neither of the homoleptic complexes 3 and 4 react with cyclopentadiene. Furthermore, the reactions of all homoleptic and heteroleptic compounds described in this manuscript with indene or fluorene do not lead to any products, which might be a consequence of the less acidic nature of these substrates $\left(\mathrm{p} K_{\mathrm{a}}\right.$ (indene $)=20.1, \mathrm{p} K_{\mathrm{a}}$ (fluorene $)=22.6$ ).

$\mathrm{X}$-ray structures of the two types of cyclopentadienyl adducts. It is instructive to compare the X-ray diffraction data for the crystalline cyclopentadienyl adducts 8a (Fig. 7) and 9 (Fig. 8).

The solid state structure of $\mathbf{8 a}$ contains a four coordinate cerium cation in a slightly distorted tetrahedral environment which is surrounded by three cyclopentadienyl ligands and the coordinated alkoxide arm of a protonated NHC imidazolium ligand (average tetrahedral angle $=109.02^{\circ}$ ). The $\mathrm{Ce}-\mathrm{Cp}_{\mathrm{Ct}}$ bond distances of $2.633 \AA$ are slightly elongated when compared to 1-Ce $(2.594 \AA), \mathrm{CeCp}_{3}(2.548 \AA)^{55}$ or the ketone adducts $\mathrm{CeCp}_{3}\left(\mathrm{Ph}_{2} \mathrm{CO}\right)^{56}$ and $\mathrm{CeCp}_{3}\left(\mathrm{C}_{13} \mathrm{H}_{8} \mathrm{O}\right) .{ }^{56}$ The retention of the $\mathrm{Ce}(\mathrm{III})$ oxidation state is supported by the $\mathrm{Ce}-\mathrm{O}$ bond length, which is in good agreement with other $\mathrm{Ce}(\mathrm{III})-\mathrm{O}$ distances and the $\mathrm{Ce}-\mathrm{Cp}_{\mathrm{Ct}}$ bond distances which are significantly longer to those found in $\mathrm{Ce}(\mathrm{Iv})-\mathrm{Cp}$ compounds, e.g. $\mathrm{CeCp}_{3} \mathrm{Cl}^{57}$

In 9, the hydrogen-bonded cyclopentadienyl anion is disordered due to its free rotation. The average $\mathrm{C}-\mathrm{C}$ bond distance of the imidazolium-trapped cyclopentadienyl anion in $\mathbf{9}$ is $1.326 \AA$ and the average $\mathrm{C}-\mathrm{C}-\mathrm{C}$ bond angle is $108.0^{\circ}$ which is comparable to those found in the closely related compound

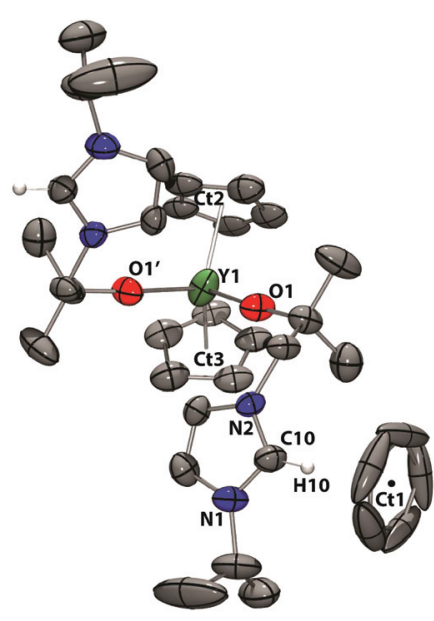

Fig. 8 Solid state structure of 9 (asymmetric unit shown). For clarity, H atoms, except the imidazolium proton, are omitted (displacement ellipsoids drawn at $50 \%$ probability).
$\left[\operatorname{Imid}_{2} \mathrm{Cp}\right]\left[\mathrm{Cp}_{2} \mathrm{YbCl}_{2}\right]^{58}$ and the "free" $\left[\mathrm{C}_{5} \mathrm{H}_{5}\right]^{-}$anion. ${ }^{59}$ The $\mathrm{C}_{\text {carbene }}-\mathrm{Cp}_{\mathrm{Ct}}$ distance is $3.214 \AA$ and therefore slightly elongated compared to those in $\left[\operatorname{Imid}_{2} \mathrm{Cp}\right]\left[\mathrm{Cp}_{2} \mathrm{YbCl}_{2}\right] 3.086(8)$ $\AA$, but still significantly shorter than, for example, in the neutral 4-methylpyridine hexamer $\left(3.85 \AA{ }^{\circ}\right){ }^{60}$ The $\mathrm{Cp}_{\mathrm{Ct}} \cdots \mathrm{H}$ bond distance is $2.227 \AA$ and almost identical to those seen in $\left[\operatorname{Imid}_{2} \mathrm{Cp}\right]\left[\mathrm{Cp}_{2} \mathrm{YbCl}_{2}\right](2.295(9) \AA)$ and consequently at the short end of the range of $\mathrm{C}-\mathrm{H} \cdots \mathrm{Cp}_{\mathrm{Ct}}$ contacts. The $\mathrm{C}_{\text {carbene }}-\mathrm{H}-\mathrm{Cp} \mathrm{p}_{\mathrm{Ct}}$ and $\mathrm{H}-\mathrm{Cp}_{\mathrm{Ct}}-\mathrm{H}$ angles are 173.61 and $178.71^{\circ}$, respectively. The two imidazolium ligands are arranged at an angle of $66^{\circ}$ with respect to each other. Due to the polymeric nature of $\mathbf{9}$, the compound is virtually insoluble in aromatic and aliphatic solvents after initial crystallisation and decomposes rapidly in pyridine or chlorinated solvents, preventing detailed NMR spectroscopic analysis.

\section{C-H acidic substrates - diphenylacetone}

The ketone 1,1-diphenylacetone is a highly reactive substrate for electropositive metals; the $\mathrm{p} K_{\mathrm{a}}$ of the most acidic $\alpha-\mathrm{H}$ is 19.4, close to that for indene, but the deprotonated molecule can coordinate to a metal centre in the enolate form. Accordingly, the reaction between $\mathbf{1 - Y}$ and one equivalent of $\mathrm{Ph}_{2} \mathrm{CHCOCH}_{3}$ in thf at $60{ }^{\circ} \mathrm{C}$ for one hour results in the formation of the zwitterionic yttrium imidazolium enolate $\mathrm{YCp}_{2}(\mathrm{LH})\left(\mathrm{O}-\mathrm{C}(\mathrm{Me})=\mathrm{CPh}_{2}\right) \mathbf{1 0}$ (Scheme 6). A similar reaction at room temperature results in a different complex 10a which we have not yet been able to characterise structurally, but which is cleanly converted into 10 upon heating to $60{ }^{\circ} \mathrm{C}$; we assume that 10a is a kinetic isomer of $\mathbf{1 0 .}$

The ${ }^{1} \mathrm{H}$ NMR spectrum of $\mathbf{1 0}$ in $\mathrm{d}^{8}$-thf contains a single resonance for both cyclopentadienyl ligands at $5.90 \mathrm{ppm}$. The characteristic resonance for imidazolium proton is present at $8.86 \mathrm{ppm}$ and thus significantly shifted to higher frequency when compared to 5 or 6 ; a ${ }^{1} \mathrm{H} /{ }^{13} \mathrm{C}$ HSQC spectrum allows the unambiguous assignment of the imidazolium proton. Besides the aromatic signals corresponding to the enolate, the spectrum also contains the other resonances of the alkoxy-tethered carbene that are slightly shifted when compared to the starting material 1-Y. The ${ }^{13} \mathrm{C}\left\{{ }^{1} \mathrm{H}\right\}$ NMR spectrum of 10 in $\mathrm{d}^{8}$-thf includes a singlet corresponding to the protonated imidazolium carbon atom at $138.8 \mathrm{ppm}$, and a doublet at $160.9 \mathrm{ppm}$ and a singlet at $111.2 \mathrm{ppm}$ which can be assigned to the two enolate alkene carbon environments.

Single crystals of $\mathbf{1 0}$ suitable for X-ray crystallography were grown from a concentrated thf solution at room temperature

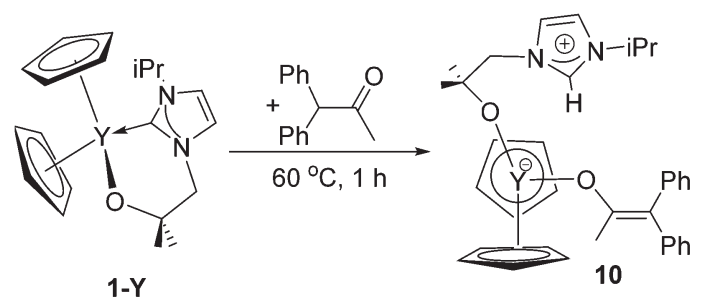

Scheme 6 Reaction of 1-Y with 1,1-diphenylacetone. 


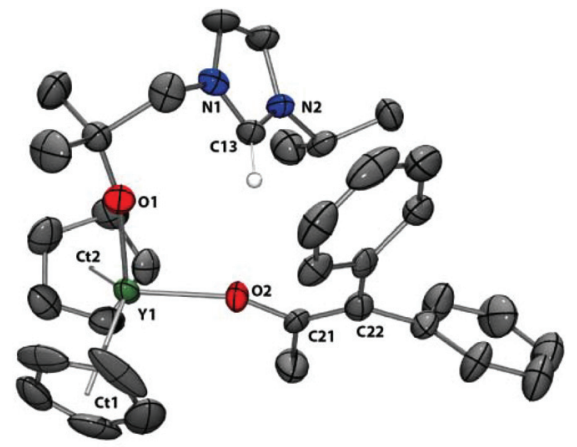

Fig. 9 Solid state structure of 10 . For clarity, $\mathrm{H}$ atoms, except the imidazolium proton, are omitted (displacement ellipsoids drawn at 50\% probability).

(Fig. 9). The yttrium centre in $\mathbf{1 0}$ is coordinated in a distorted tetrahedral coordination environment (average angle 111.3 ${ }^{\circ}$ ) by two cyclopentadienyl ligands, a pendant alkoxy-tethered imidazolium ligand and the diphenylenolate group. The geometrical data for the two cyclopentadienyl ligands and the pendant ligand in $\mathbf{1 0}$ are almost identical to those observed for 5 and 6. The $\mathrm{Y}-\mathrm{O}$ bond length of the coordinated enolate is 2.149(5) A, slightly longer than the corresponding Y-O length of the alkoxy tether present in the same molecule, but both $\mathrm{Y}-\mathrm{O}$ distances fall within the expected range. The C21-C22 distance in the enolate is 1.373(11) $\AA$ and thus slightly elongated when compared to the related compounds $\mathrm{ZrCp}_{2}(\mathrm{Me})$ $\left(\mathrm{O}-\mathrm{C}(\mathrm{Me})=\mathrm{CPh}_{2}\right)(1.337(8) \AA)$ and $\mathrm{ZrCp}_{2}\left(\mathrm{O}-\mathrm{C}(\mathrm{Me})=\mathrm{CPh}_{2}\right)_{2}$ (1.34(1) and 1.33(1) А̊). ${ }^{61}$

\section{Conclusions}

\section{$\mathrm{N}-\mathrm{H}$-cleavable substrates $\mathrm{p} K_{\mathrm{a}}$ 21-23 (pyrrole and indole)}

Complex 1-Y is very reactive towards the heterolytic cleavage of the $\mathrm{N}-\mathrm{H}$ bond of pyrrole and indole across the metal-carbene bond. Control reactions show that it is the $\mathrm{NH}$ and not the ortho $\mathrm{C}-\mathrm{H}$ bond that is cleaved in a kinetically and thermodynamically preferred step. The fact that 1-Ce does not react with these substrates could be due to the presence of THF, which is a sufficiently strongly coordinating ligand that prevents access to this larger metal cation (the $\mathrm{Y}$ complex never coordinates $\mathrm{THF}$ ), or that the Ce cation is insufficiently Lewis acidic to engender heterolytic $\mathrm{N}-\mathrm{H}$ cleavage across the $\mathrm{Ce}-\mathrm{C}$ bond. The homoleptic alkoxy-tethered NHC complexes $\mathbf{3}$ and $\mathbf{4}$ that have many (3 or 4) coordinated alkoxide groups are presumably insufficiently Lewis acidic at the metal centre to cleave the $\mathrm{N}-\mathrm{H}$ bond, but still capable of forming hydrogen-bonded adducts with the substrates.

\section{C-H-cleavable substrates $\mathrm{p}_{\mathrm{a}}$ 25-29 (alkyne); 18 (cyclopentadiene); 20-22 (indene and fluorene); 19 (1,1'-diphenylacetone)}

Complexes $\mathbf{1}$ (Y and $\mathbf{S c}$ ) which were reactive towards $\mathrm{N}-\mathrm{H}$ cleavage do not form products of $\mathrm{C}-\mathrm{H}$ cleavage even with the highly acidic $\mathrm{C}-\mathrm{H}$ substrate $\mathrm{CpH}$, although there appears to be a dynamic equilibrium process occurring, presumably involving a reversible $\mathrm{C}-\mathrm{H}$ addition process, since the $\mathrm{CpH}$ substrate does not dimerise under these reaction conditions. The mono(carbene) and bis(carbene) complexes $\mathbf{1}$ and 2, respectively, both react with $\mathrm{CpH}$ to form zwitterionic metal cyclopentadienyl complexes that incorporate protonated imidazolium groups. In 2, due to the presence of two $\mathrm{Y}-\mathrm{C}(\mathrm{NHC})$ bonds, this results in a polymeric complex with the very rare $\mathrm{H}^{+}-\left[\mathrm{C}_{5} \mathrm{H}_{5}\right]-\mathrm{H}^{+}$ motif, previously only observed in $\left[\operatorname{Imid}_{2} \mathrm{Cp}\right]\left[\mathrm{Cp}_{2} \mathrm{YbCl}_{2}\right] \cdot{ }^{58}$ It is notable that the other carbocycles indene and fluorene do not react, despite their high carbon $\mathrm{C}-\mathrm{H}$ acidity. The substrates with less acidic $\mathrm{E}-\mathrm{H}$ bonds that can form a thermodynamically stronger Ln-E bond, in particular Ln-N (5 and 6 from pyrrole and indole respectively) and Ln-O (10 from diphenylacetone), readily form $\mathrm{M}-\mathrm{NHC}$ addition products.

Finally, the observation that a reaction of 1-Ce with alkynes occurs (albeit to rearrange to the known $\mathrm{Cp}$ adduct and polymerised alkynide materials), suggests that the strength of the $\mathrm{Ce}-\mathrm{C} \equiv \mathrm{CR}$ bond provides an excellent driving force for these reactions. Work is in progress to isolate the alkynide adducts and to pursue secondary substrate insertion chemistry of these activated substrates that could lead to useful functionalised products and catalytic chemical cycles.

\section{Experimental}

\section{General procedures}

All manipulations were carried out under a dry, oxygen-free dinitrogen atmosphere using standard Schlenk techniques or in a glovebox unless otherwise stated. Solvents (toluene, hexane and THF) were dried by passage activated $4 \AA$ molecular sieve towers, stored over activated $4 \AA$ molecular sieves and degassed three times prior to use. Deuterated solvents were refluxed over potassium, vacuum transferred and freezepump-thaw degassed three times prior to use. $\operatorname{LnCp}_{3}(\mathrm{Ln}=\mathrm{Sc}$, $\mathrm{Y}, \mathrm{Ce}),{ }^{62}$ compound $3^{32}$ and $\mathrm{KL}^{63}$ were synthesised according to literature procedures. All other reagents were used as purchased. ${ }^{1} \mathrm{H}$ NMR spectra were recorded at $298 \mathrm{~K}$ unless otherwise stated on a Bruker AVA500 at $500 \mathrm{MHz} .{ }^{13} \mathrm{C}$ and ${ }^{13} \mathrm{C}\left\{{ }^{1} \mathrm{H}\right\}$ NMR spectra were recorded at $298 \mathrm{~K}$ on a Bruker AVA500 at 125.77 MHz. The ${ }^{1} \mathrm{H},{ }^{13} \mathrm{C}$ and ${ }^{13} \mathrm{C}\left\{{ }^{1} \mathrm{H}\right\}$ NMR spectra were referenced internally to residual protio solvent $\left({ }^{1} \mathrm{H}\right)$ or solvent $\left({ }^{13} \mathrm{C}\right)$ and are reported to tetramethylsilane $(\delta=0 \mathrm{ppm})$. Chemical shifts are quoted in $\delta(\mathrm{ppm})$ and coupling constants in $\mathrm{Hz}$. Elemental analyses were determined by Mr Stephen Boyer at London Metropolitan University and Medac Ltd. Crystallographic data were collected on an Oxford Diffraction Xcalibur diffractometer using graphite-monochromated Mo $\mathrm{K} \alpha$ radiation $(\lambda=0.71073 \AA)$. Cif files were deposited with the CCDC, codes 1003236-1003246.

1-Sc - $\mathrm{Sc}(\mathrm{Cp})_{3}(0.300 \mathrm{~g}, 1.25 \mathrm{mmol})$ and $\mathrm{KL}(0.274 \mathrm{~g}$, $1.25 \mathrm{mmol})$ were combined in an ampoule and thf $(20 \mathrm{~mL})$ added. The reaction mixture was heated to reflux for 2 hours to afford a yellow solution. Upon allowing to cool to room 
temperature, colourless crystals of KCp formed. The solution was decanted away from the KCp into a Schlenk and the yellow solution of product 1-Sc was concentrated to the point of crystallisation, then cooled to $-30{ }^{\circ} \mathrm{C}$. Yellow crystals of 1-Sc were isolated by filtration and dried under reduced pressure. Yield: $0.210 \mathrm{~g}, 47 \%$.

${ }^{1} \mathrm{H}$ NMR $\left(\mathrm{C}_{6} \mathrm{D}_{6}, 400 \mathrm{MHz}\right): 6.36$ (s, br, $\left.1 \mathrm{H}, \mathrm{NCHCHN}\right), 6.13$ (s, br, $1 \mathrm{H}, \mathrm{NCHCHN}), 6.12\left(\mathrm{~s}, 10 \mathrm{H}, \mathrm{C}_{5} H_{5}\right), 4.22\left(\mathrm{sept},{ }^{3} J_{\mathrm{HH}}=6.8\right.$ $\left.\mathrm{Hz}, 1 \mathrm{H}, \mathrm{C} H \mathrm{Me}_{2}\right), 3.24\left(\mathrm{~s}, 2 \mathrm{H}, \mathrm{CH}_{2} \mathrm{CMe}_{2} \mathrm{O}\right), 1.09$ (s, 6H, $\mathrm{CH}_{2} \mathrm{CMe}_{2} \mathrm{O}$ ), 0.99 (d, $J=6.7 \mathrm{~Hz}, 6 \mathrm{H}, \mathrm{CHMe}$ ); Anal. Found (Calcd for $\mathrm{C}_{20} \mathrm{H}_{27} \mathrm{~N}_{2} \mathrm{O}_{1} \mathrm{Sc}$ ): C, $67.40(67.26) \mathrm{H}, 7.64$ (7.57), N, 7.86 (7.72).

1-Y - Following a similar procedure for 1-Sc, to a suspension of $\mathrm{YCp}_{3}(0.30 \mathrm{~g}, 1.06 \mathrm{mmol})$ in thf $(10 \mathrm{~mL})$ were added $\mathrm{KL}$ $(0.230 \mathrm{~g}, 1.05 \mathrm{mmol})$ in thf $(10 \mathrm{~mL})$, and the resulting reaction mixture was heated to reflux for 30 min to afford a yellow solution. Upon allowing to cool to room temperature, colourless crystals of KCp formed. The solution was decanted away from the KCp into a Schlenk and the solvent was removed under reduced pressure until colourless crystals of 1-Y began to form, then cooled to $-30{ }^{\circ} \mathrm{C}$. Colourless crystalline 1-Y was isolated by filtration and dried under reduced pressure. Yield: $0.316 \mathrm{~g}$, $78 \%$.

${ }^{1} \mathrm{H}$ NMR $\left(\mathrm{C}_{6} \mathrm{D}_{6}, 400 \mathrm{MHz}\right): 6.20\left(\mathrm{~s}, 10 \mathrm{H}, \mathrm{C}_{5} H_{5}\right), 6.17\left(\mathrm{~d},{ }^{3} \mathrm{~J}_{\mathrm{HH}}\right.$ $=1.6 \mathrm{~Hz}, 1 \mathrm{H}, \mathrm{NCHCHN}), 6.14\left(\mathrm{~d},{ }^{3} J_{\mathrm{HH}}=1.6 \mathrm{~Hz}, 1 \mathrm{H}, \mathrm{NCHCHN}\right)$, $4.18\left(\mathrm{sept},{ }^{3} J_{\mathrm{HH}}=6.8 \mathrm{~Hz}, 1 \mathrm{H}, \mathrm{CHMe}\right.$ ), $3.34\left(\mathrm{~s}, 2 \mathrm{H}, \mathrm{CH}_{2} \mathrm{CMe}_{2} \mathrm{O}\right)$, 1.09 (s, 6H, $\mathrm{CH}_{2} \mathrm{CMe}_{2} \mathrm{O}$ ), 1.01 (d, J = 6.8 Hz, 6H, $\mathrm{CHMe}_{2}$ ).

${ }^{13} \mathrm{C}$ NMR $\left(\mathrm{C}_{6} \mathrm{D}_{6}, 126 \mathrm{MHz}\right): 192.06\left(\mathrm{~d},{ }^{1} J_{\mathrm{YC}}=47.6 \mathrm{~Hz}, \mathrm{NCN}\right)$, 124.00 (s, NCHCHN), 113.82 (s, NCHCHN), 109.49 (s, $C_{5} \mathrm{H}_{5}$ ) $72.26\left(\mathrm{~d}, J=3.7 \mathrm{~Hz}, \mathrm{CMe}_{2}\right), 65.62\left(\mathrm{~s}, \mathrm{OCMe}_{2} \mathrm{CH}_{2}\right), 52.80(\mathrm{~s}$, $\mathrm{CHMe}_{2}$ ), 29.08 (s, $\mathrm{CH}_{2} \mathrm{CMe}_{2} \mathrm{O}$ ), 23.37 (s, $\mathrm{CHMe}_{2}$ ); ${ }^{1} \mathrm{H}$ NMR (d ${ }^{8}-$ thf, $500 \mathrm{MHz}): 7.22\left(\mathrm{~d},{ }^{3} \mathrm{HH}_{\mathrm{HH}}=1.7 \mathrm{~Hz}, 1 \mathrm{H}, \mathrm{NCHCHN}\right), 7.06(\mathrm{~d}$, $\left.{ }^{3} J_{\mathrm{HH}}=1.6 \mathrm{~Hz}, 1 \mathrm{H}, \mathrm{NCHCHN}\right), 5.91\left(\mathrm{~s}, 10 \mathrm{H}, \mathrm{C}_{5} H_{5}\right), 4.54$ (sept, ${ }^{3} J_{\mathrm{HH}}=6.7 \mathrm{~Hz}, 1 \mathrm{H}, \mathrm{CHMe}$ ), $3.69\left(\mathrm{~s}, 2 \mathrm{H}, \mathrm{CH}_{2} \mathrm{CMe}_{2} \mathrm{O}\right), 1.56(\mathrm{~d}$, $\left.J=6.7 \mathrm{~Hz}, 6 \mathrm{H}, \mathrm{CHMe} e_{2}\right), 0.93\left(\mathrm{~s}, 6 \mathrm{H}, \mathrm{CH}_{2} \mathrm{CMe}_{2} \mathrm{O}\right) ;{ }^{13} \mathrm{C} \mathrm{NMR}$ (d ${ }^{8}$-thf, $\left.126 \mathrm{MHz}\right): 192.99$ (d, $\left.{ }^{1} J_{\mathrm{YC}}=46.1 \mathrm{~Hz}, \mathrm{NCN}\right), 125.22(\mathrm{~s}$, NCHCHN), 115.42 (s, NCHCHN), $109.34\left(\mathrm{~s}, C_{5} \mathrm{H}_{5}\right) 72.60$ (d, $J=$ $3.6 \mathrm{~Hz}, \mathrm{CMe}_{2}$ ), 66.03 (s, $\mathrm{OCMe}_{2} \mathrm{CH}_{2}$ ), 53.71 (s, $\mathrm{CHMe}_{2}$ ), 29.38 (s, $\mathrm{CH}_{2} \mathrm{CMe}_{2} \mathrm{O}$ ), 24.05 (s, $\mathrm{CHMe}_{2}$ ); Anal. Found (Calcd for $\mathrm{C}_{20} \mathrm{H}_{27} \mathrm{~N}_{2} \mathrm{O}_{1} \mathrm{Y}$ ): C, 60.21 (60.00), H, 6.99 (6.80), N, 7.27 (7.00).

1-Ce was prepared according to the method described above for the synthesis of 1-Y. It should be noted that the coordinated thf molecule observed in the solid-state structure is lost upon drying under vacuum. Yield: $0.342 \mathrm{~g}, 75 \%$.

Anal. Found (Calcd for $\mathrm{C}_{20} \mathrm{H}_{27} \mathrm{~N}_{2} \mathrm{O}_{1} \mathrm{Ce}$ ): C, 52.99 (53.20), H, 6.00 (6.03), N, 6.21 (6.20).

2-Y - Following the same procedure mentioned above for the synthesis of $\mathbf{1 - Y}$, to a suspension of $\mathrm{YCp}_{3}(0.30 \mathrm{~g}$, $1.06 \mathrm{mmol})$ in thf $(10 \mathrm{~mL})$ was added $\mathrm{KL}(0.460 \mathrm{~g}, 2.10 \mathrm{mmol})$ in thf $(15 \mathrm{~mL})$, and the resulting reaction mixture was heated to reflux for $45 \mathrm{~min}$ to afford a yellow solution. Upon allowing to cool to room temperature, colourless crystals of $\mathrm{KCp}$ formed. The solution was decanted away from the KCp into a Schlenk and the solvent was slowly removed under reduced pressure until colourless crystals of 2 began to form. Further crystals of 2 were afforded by cooling to $-30^{\circ} \mathrm{C}$. These crystals were isolated by filtration and dried under reduced pressure. Yield: $0.381 \mathrm{~g}, 71 \%$.

${ }^{1} \mathrm{H}$ NMR $\left(\mathrm{C}_{6} \mathrm{D}_{6}, 500 \mathrm{MHz}\right): 6.53\left(\mathrm{~s}, 5 \mathrm{H}, \mathrm{C}_{5} H_{5}\right), 6.37\left(\mathrm{~d},{ }^{3} J_{\mathrm{HH}}=\right.$ $1.6 \mathrm{~Hz}, 2 \mathrm{H}, \mathrm{NCHCHN}), 6.20\left(\mathrm{~d},{ }^{3} \mathrm{JHH}_{\mathrm{HH}}=1.6 \mathrm{~Hz}, 2 \mathrm{H}, \mathrm{NCHCHN}\right)$, $5.73\left(\mathrm{sept},{ }^{3} \mathrm{~J}_{\mathrm{HH}}=6.8 \mathrm{~Hz}, 2 \mathrm{H}, \mathrm{CHMe}\right), 3.82\left(\mathrm{~d},{ }^{3} J_{\mathrm{HH}}=12.5 \mathrm{~Hz}\right.$, $2 \mathrm{H}, \mathrm{CH}_{2} \mathrm{CMe}_{2} \mathrm{O}$ ), $3.30\left(\mathrm{~d},{ }^{3} J_{\mathrm{HH}}=12.5 \mathrm{~Hz}, 2 \mathrm{H}, \mathrm{CH}_{2} \mathrm{CMe}_{2} \mathrm{O}\right), 1.31$ (s, 6H, $\mathrm{CH}_{2} \mathrm{CMe}_{2} \mathrm{O}$ ), 1.28 (d, $J=6.8 \mathrm{~Hz}, 6 \mathrm{H}, \mathrm{CHMe}_{2}$ ), 1.26 (d, $J=$ $\left.6.8 \mathrm{~Hz}, 6 \mathrm{H}, \mathrm{CHMe}_{2}\right), 0.77\left(\mathrm{~s}, 6 \mathrm{H}, \mathrm{CH}_{2} \mathrm{CMe}_{2} \mathrm{O}\right) ;{ }^{13} \mathrm{C} \mathrm{NMR}\left(\mathrm{C}_{6} \mathrm{D}_{6}\right.$, $126 \mathrm{MHz}): 194.33\left(\mathrm{~d},{ }^{1} J_{\mathrm{YC}}=37.3 \mathrm{~Hz}, \mathrm{NCN}\right), 121.97(\mathrm{~s}$, NCHCHN), 113.14 (s, NCHCHN), 108.69 (s, $\left.C_{5} \mathrm{H}_{5}\right) 71.10$ (d, $J=$ $2.9 \mathrm{~Hz}, \mathrm{CMe}_{2}$ ), 65.30 (s, $\mathrm{OCMe}_{2} \mathrm{CH}_{2}$ ), 50.76 (s, $C \mathrm{HMe}_{2}$ ), 31.22 (s, $\left.\mathrm{CH}_{2} \mathrm{CMe}_{2} \mathrm{O}\right), 28.84\left(\mathrm{~s}, \mathrm{CH}_{2} \mathrm{CMe}_{2} \mathrm{O}\right), 24.36\left(\mathrm{~s}, \mathrm{CHMe} e_{2}\right), 23.39$ (s, $\mathrm{CHMe}_{2}$ ); ${ }^{1} \mathrm{H}$ NMR (d ${ }^{8}$-thf, $500 \mathrm{MHz}$ ): $7.02\left(\mathrm{~d},{ }^{3} J_{\mathrm{HH}}=1.6 \mathrm{~Hz}\right.$, $2 \mathrm{H}, \mathrm{NCHCHN}), 6.88\left(\mathrm{~d},{ }^{3} J_{\mathrm{HH}}=1.6 \mathrm{~Hz}, 2 \mathrm{H}, \mathrm{NCHCHN}\right), 6.00(\mathrm{~s}$, $\left.5 \mathrm{H}, \mathrm{C}_{5} H_{5}\right), 5.63\left(\mathrm{sept},{ }^{3} J_{\mathrm{HH}}=6.8 \mathrm{~Hz}, 2 \mathrm{H}, \mathrm{CHMe}_{2}\right), 3.80(\mathrm{~d}$, $\left.{ }^{3} J_{\mathrm{HH}}=12.4 \mathrm{~Hz}, 2 \mathrm{H}, \mathrm{CH}_{2} \mathrm{CMe}_{2} \mathrm{O}\right), 3.70\left(\mathrm{~d},{ }^{3} \mathrm{~J}_{\mathrm{HH}}=12.4 \mathrm{~Hz}, 2 \mathrm{H}\right.$, $\mathrm{CH}_{2} \mathrm{CMe}_{2} \mathrm{O}$ ), 1.45 (d, $J=6.8 \mathrm{~Hz}, 6 \mathrm{H}, \mathrm{CHMe}_{2}$ ), 1.40 (d, $J=$ $\left.6.8 \mathrm{~Hz}, 6 \mathrm{H}, \mathrm{CHMe} e_{2}\right), 1.15\left(\mathrm{~s}, 6 \mathrm{H}, \mathrm{CH}_{2} \mathrm{CMe}_{2} \mathrm{O}\right), 0.60(\mathrm{~s}, 6 \mathrm{H}$, $\mathrm{CH}_{2} \mathrm{CMe}_{2} \mathrm{O}$ ); ${ }^{13} \mathrm{C}$ NMR (d ${ }^{8}$-thf, $\left.101 \mathrm{MHz}\right): 194.79\left(\mathrm{~d},{ }^{1} J_{\mathrm{YC}}=37.5\right.$ $\mathrm{Hz}, \mathrm{NCN}$ ), 122.99 (s, NCHCHN), 114.25 (s, NCHCHN), 108.58 $\left(\mathrm{s}, C_{5} \mathrm{H}_{5}\right), 71.72(\mathrm{~d}, J=2.9 \mathrm{~Hz}, C \mathrm{CMe} 2), 65.84(\mathrm{~s}, \mathrm{OCMe} 2 \mathrm{CH} 2)$, 51.47 (s, $\mathrm{CHMe}_{2}$ ), 31.39 (s, $\mathrm{CH}_{2} \mathrm{CMe}_{2} \mathrm{O}$ ), 29.00 (s, $\mathrm{CH}_{2} \mathrm{CMe}_{2} \mathrm{O}$ ), 24.66 (s, $\mathrm{CHMe}_{2}$ ), 23.68 (s, $\mathrm{CHMe}_{2}$ ); Anal. Found (Calcd for $\mathrm{C}_{25} \mathrm{H}_{39} \mathrm{~N}_{4} \mathrm{O}_{2} \mathrm{Y}$ ): C, 58.00 (58.13), H, 7.29 (7.61), N, 10.51 (10.85).

4 - KL $(500 \mathrm{mg}, 2.27 \mathrm{mmol}, 4$ eq. $)$ and $\mathrm{ThCl}_{4}\left(\mathrm{dme}_{2}\right.$ (320 mg, $0.58 \mathrm{mmol}, 1$ eq.) were dissolved in thf and stirred for $c a .1 \mathrm{~h}$ before the solvent was removed under reduced pressure. Toluene was added and the suspension was filtered and washed with toluene. The solvent was then half removed in vacuum and the resulting solution cooled to $-30{ }^{\circ} \mathrm{C}$ yielding colourless crystals $(455 \mathrm{mg}, 82 \%) .{ }^{1} \mathrm{H}$ NMR $\left(303 \mathrm{~K}, \mathrm{C}_{6} \mathrm{D}_{6}\right)$ $\delta 6.53(\mathrm{~s}, 4 \mathrm{H}, \mathrm{CH}), 6.38(\mathrm{~s}, 4 \mathrm{~h}, \mathrm{CH}), 6.02\left(\right.$ br. S, $\left.4 \mathrm{H}, \mathrm{CH}\left(\mathrm{CH}_{3}\right)_{2}\right)$, 3.44 (br. S, $\left.8 \mathrm{H}, \mathrm{CH}_{2}\right), 1.30$ (br s., $48 \mathrm{H}, \mathrm{C}\left(\mathrm{CH}_{3}\right)_{2}$ and $\left.\mathrm{CH}\left(\mathrm{CH}_{3}\right)_{3}\right)$ $\mathrm{ppm} ;{ }^{1} \mathrm{H}$ NMR $\left(343 \mathrm{~K}, \mathrm{C}_{6} \mathrm{D}_{6}\right) \delta 6.56(\mathrm{~s}, 4 \mathrm{H}, \mathrm{CH}), 6.48(\mathrm{~s}, 4 \mathrm{H}$, $\mathrm{CH}$ ), 5.88 (sept., $\left.J=6.46 \mathrm{~Hz}, 4 \mathrm{H}, \mathrm{CH}\left(\mathrm{CH}_{3}\right)_{2}\right), 3.81\left(\mathrm{~s}, 8 \mathrm{H}, \mathrm{CH}_{2}\right)$, $1.27\left(\mathrm{~d}, J=6.45 \mathrm{~Hz}, 24 \mathrm{H}, \mathrm{CH}\left(\mathrm{CH}_{3}\right)_{2}\right), 1.13\left(\mathrm{~s}, 24 \mathrm{H}, \mathrm{C}\left(\mathrm{CH}_{3}\right)_{2}\right)$ $\mathrm{ppm} ;{ }^{1} \mathrm{H}$ NMR $\left(213 \mathrm{~K}, \mathrm{THF}-\mathrm{C}_{6} \mathrm{D}_{6}\right) \delta 6.85(\mathrm{~s}, 2 \mathrm{H}, \mathrm{CH}), 6.71(\mathrm{~s}$, $2 \mathrm{H}, \mathrm{CH}), 6.62(\mathrm{~s}, 2 \mathrm{H}, \mathrm{CH}), 6.49$ (s, 2H, CH), 6.10 (sept., $J=6.46$ $\left.\mathrm{Hz}, 2 \mathrm{H}, \mathrm{CH}\left(\mathrm{CH}_{3}\right)_{2}\right), 5.71$ (sept., $J=6.46 \mathrm{~Hz}, 2 \mathrm{H}, \mathrm{CH}\left(\mathrm{CH}_{3}\right)_{2}$ ), $4.79\left(\mathrm{~d}, J=11.55 \mathrm{~Hz}, 2 \mathrm{H}, \mathrm{CH}_{2}\right), 3.7-3.2$ (missing doublet under THF, 2H), 3.18 (d, $\left.J=11.55 \mathrm{~Hz}, 2 \mathrm{H}, \mathrm{CH}_{2}\right), 3.03(\mathrm{~d}, J=11.55 \mathrm{~Hz}$, $2 \mathrm{H}, \mathrm{CH}_{2}$ ), 1.75-1.25 (two missing singlets under THF, 24H), $1.23\left(\mathrm{~d}, J=6.45 \mathrm{~Hz}, 6 \mathrm{H}, \mathrm{CH}\left(\mathrm{CH}_{3}\right)_{2}\right), 0.48(\mathrm{~d}, J=6.45 \mathrm{~Hz}, 12 \mathrm{H}$, $\left.\mathrm{CH}\left(\mathrm{CH}_{3}\right)_{2}\right), 0.36\left(\mathrm{~d}, J=6.45 \mathrm{~Hz}, 6 \mathrm{H}, \mathrm{CH}\left(\mathrm{CH}_{3}\right)_{2}\right) \mathrm{ppm} ; 13 \mathrm{C}$ $\left(303 \mathrm{~K}, \mathrm{C}_{6} \mathrm{D}_{6}\right) \delta 210.3(\mathrm{NCN}), 121.8(\mathrm{CH}), 113.1(\mathrm{CH}), 75.21$ $\left(\mathrm{CH}_{2}\right), 64.3\left(\mathrm{C}\left(\mathrm{CH}_{3}\right)_{2}\right), 51.2\left(\mathrm{CH}\left(\mathrm{CH}_{3}\right)_{2}\right), 29.1\left(\mathrm{CH}_{3}\right) 24.0\left(\mathrm{CH}_{3}\right)$. Anal. Found (Calcd for $\mathrm{C}_{40} \mathrm{H}_{72} \mathrm{~N}_{8} \mathrm{O}_{4} \mathrm{Th}$ ): C, 46.59 (49.99), H, 9.32 (7.55), N, 10.07 (11.66).

5 - To a solution of freshly prepared 1-Y $(0.20 \mathrm{~g}, 0.50 \mathrm{mmol})$ in thf $(5 \mathrm{~mL})$ was added pyrrole $(0.034 \mathrm{~g}, 0.50 \mathrm{mmol})$ and the resulting mixture was stirred at room temperature for $1 \mathrm{~h}$, during which time a colourless precipitate formed. The precipitate was collected by filtration, washed with hexanes $(3 \times$ $3 \mathrm{~mL}$ ) and dried under vacuum to afford 3 as a colourless material. Yield: $0.159 \mathrm{~g}$ (68\%). Diffraction-quality crystals were grown from a concentrated thf solution at room temperature. 
${ }^{1} \mathrm{H}$ NMR (d ${ }^{8}$-thf, $\left.500 \mathrm{MHz}\right): 7.38\left(\mathrm{~d},{ }^{3} J_{\mathrm{HH}}=1.9 \mathrm{~Hz}, 1 \mathrm{H}\right.$, $\mathrm{NCHCHN}), 7.12\left(\mathrm{~d},{ }^{3} \mathrm{JHH}_{\mathrm{HH}}=1.9 \mathrm{~Hz}, 1 \mathrm{H}, \mathrm{NCHCHN}\right), 6.86(\mathrm{t}$, $\left.{ }^{3} J_{\mathrm{HH}}=1.6 \mathrm{~Hz}, 2 \mathrm{H}, \mathrm{NCHCH}\right), 6.32(\mathrm{~s}, \mathrm{br}, H \mathrm{CNN}), 5.99\left(\mathrm{t},{ }^{3} J_{\mathrm{HH}}=\right.$ $1.6 \mathrm{~Hz}, 2 \mathrm{H}, \mathrm{NCHCH}), 5.89\left(\mathrm{~s}, 10 \mathrm{H}, \mathrm{C}_{5} H_{5}\right), 4.46\left(\mathrm{sept},{ }^{3} J_{\mathrm{HH}}=\right.$ $6.7 \mathrm{~Hz}, 1 \mathrm{H}, \mathrm{CHMe}$ ), $3.74\left(\mathrm{~s}, 2 \mathrm{H}, \mathrm{CH}_{2} \mathrm{CMe}_{2} \mathrm{O}\right), 1.37$ (d, $J=$ $6.7 \mathrm{~Hz}, 6 \mathrm{H}, \mathrm{CH}, 1.07$ (s, 6H, $\mathrm{CH}_{2} \mathrm{CMe}_{2} \mathrm{O}$ ); ${ }^{13} \mathrm{C} \mathrm{NMR}\left(\mathrm{d}^{8}\right.$-thf, $126 \mathrm{MHz}$ ): 138.8 (s, NCHN), 129.2 (s, pyrrole $\mathrm{CH}$ ), 125.1 (s, NCHCHN), 118.1 ( $\mathrm{NCHCHN}), 109.5$ (s, $\left.C_{5} \mathrm{H}_{5}\right), 107.24$ (s, pyrrole $\mathrm{CH}$ ), $72.2\left(\mathrm{~d}, J=5.8 \mathrm{~Hz}, \mathrm{CMe}_{2}\right), 63.3\left(\mathrm{CH}_{2} \mathrm{CMe}_{2} \mathrm{O}\right), 53.5$ $\left(\mathrm{HCMe}_{2}\right), 30.1\left(\mathrm{CH}_{2} \mathrm{CMe}{ }_{2} \mathrm{O}\right), 22.9\left(\mathrm{CHMe}_{2}\right) \mathrm{ppm}$; Anal. Found (Calcd for $\mathrm{C}_{24} \mathrm{H}_{32} \mathrm{~N}_{3} \mathrm{O}_{1} \mathrm{Y}$ ): C, 62.10 (61.67), H, 6.96 (6.90), N, 9.12 (8.99).

6 - Following the procedure for 3 , to a solution of freshly prepared 1-Y $(0.20 \mathrm{~g}, 0.50 \mathrm{mmol})$ in thf $(5 \mathrm{~mL})$ was added indole $(0.059 \mathrm{~g}, 0.50 \mathrm{mmol})$ and the resulting mixture was stirred at room temperature for $1 \mathrm{~h}$, during which time a colourless precipitate formed. The precipitate was collected by filtration, washed with hexanes $(3 \times 3 \mathrm{~mL})$ and dried in vacuo to afford 4 as a colourless material. Yield: $0.183 \mathrm{~g}$ (71\%). Diffraction-quality crystals were grown from a concentrated thf solution at room temperature.

${ }^{1} \mathrm{H}$ NMR (d ${ }^{8}$-thf, $\left.500 \mathrm{MHz}\right): 7.64\left(\mathrm{~d},{ }^{3} J_{\mathrm{HH}}=8.1 \mathrm{~Hz}, 1 \mathrm{H}\right.$, $\left.\mathrm{NC}_{8} \mathrm{H}_{6}\right), 7.48\left(\mathrm{~d},{ }^{3} J_{\mathrm{HH}}=2.5 \mathrm{~Hz}, 1 \mathrm{H}, \mathrm{NC}_{8} \mathrm{H}_{6}\right), 7.42\left(\mathrm{~d},{ }^{3} J_{\mathrm{HH}}=\right.$ $7.7 \mathrm{~Hz}, 1 \mathrm{H}, \mathrm{NC}_{8} \mathrm{H}_{6}$ ), 7.37 (s, br, HCNN), $7.27(\mathrm{~s}, \mathrm{br}, 1 \mathrm{H}$, NCHCHN), 7.22 (s, br, 1H, NCHCHN), 6.81 (dt, $6.5 \mathrm{~Hz}, 1.0 \mathrm{~Hz}$, $\left.\mathrm{NC}_{8} \mathrm{H}_{6}\right), 6.72\left(\mathrm{dt}, 6.5 \mathrm{~Hz}, 1.0 \mathrm{~Hz}, \mathrm{NC}_{8} \mathrm{H}_{6}\right), 6.36\left(\mathrm{~d},{ }^{3} J_{\mathrm{HH}}=\right.$ $\left.2.5 \mathrm{~Hz}, 1 \mathrm{H}, \mathrm{NC}_{8} \mathrm{H}_{6}\right), 5.92\left(\mathrm{~s}, 10 \mathrm{H}, \mathrm{C}_{5} H_{5}\right), 3.83(\mathrm{~s}, 2 \mathrm{H}$, $\mathrm{CH}_{2} \mathrm{CMe}_{2} \mathrm{O}$ ), 3.24 (sept, ${ }^{3} J_{\mathrm{HH}}=6.7 \mathrm{~Hz}, 1 \mathrm{H}, \mathrm{CHMe}$ ), $1.22(\mathrm{~s}, 6 \mathrm{H}$, $\left.\mathrm{CH}_{2} \mathrm{CMe}_{2} \mathrm{O}\right) 0.96$ (d, $\left.J=6.7 \mathrm{~Hz}, 6 \mathrm{H}, \mathrm{CHMe} 2\right) ;{ }^{13} \mathrm{C} \mathrm{NMR}\left(\mathrm{d}^{8}\right.$-thf, $126 \mathrm{MHz}$ ): 147.9 (s, indole $\mathrm{C}$ ), 138.9 (s, indole, $\mathrm{CH}$ ), 137.2 (s, $\mathrm{NCHN}$ ), 132.3 (s, indole $\mathrm{C}$ ), 124.8 (s, $\mathrm{NCHCHN}), 119.6$ (s, indole $\mathrm{CH}$ ), 118.3 (s, NCHCHN), 118.0 (s, indole $\mathrm{CH}$ ), 117.5 (s, indole $\mathrm{CH}), 117.0$ (s, indole $\mathrm{CH}), 109.6\left(\mathrm{~s}, C_{5} \mathrm{H}_{5}\right), 71.4(\mathrm{~d}, J=$ $5.5 \mathrm{~Hz}, \mathrm{CMe}_{2}$ ), 62.8 (s, $\mathrm{CH}_{2} \mathrm{CMe}_{2} \mathrm{O}$ ), 52.3 (s, $\mathrm{HCMe}_{2}$ ), 30.3 (s, $\mathrm{CH}_{2} \mathrm{CMe}_{2} \mathrm{O}$ ), 22.5 (s, $\mathrm{CHMe}$ ) ppm; Anal. Found (Calcd for $\mathrm{C}_{28} \mathrm{H}_{34} \mathrm{~N}_{3} \mathrm{O}_{1} \mathrm{Y}$ ): C, 65.32 (64.99), H, 6.28 (6.62), N, 8.13 (8.12).

7-3 (0.068 g, $0.11 \mathrm{mmol})$ and pyrrole $(0.008 \mathrm{~g}, 0.11 \mathrm{mmol})$ were combined in benzene $(2 \mathrm{~mL})$ resulting in a yellow solution. Hexane was slowly diffused into the reaction mixture affording large yellow crystals of $6 .{ }^{1} \mathrm{H}$ NMR $\left(\mathrm{C}_{6} \mathrm{D}_{6}, 500 \mathrm{MHz}\right.$, 298 K): 11.61 (br s, 1H, NH), 7.06 (br s, 2H, pyrrole $\mathrm{CH}$ ), 6.43 (br s, 2H, pyrrole $\mathrm{CH}), 6.34\left(\mathrm{~s}, 3 \mathrm{H}, \mathrm{CHMe} \mathrm{Me}_{2}\right), 6.30(\mathrm{~s}, 3 \mathrm{H}$, $\mathrm{NCHCHN}$ ), 5.69 (s, 3H, CHMe $\mathrm{M}_{2}$, 3.96 (s, 6H, $\left.\mathrm{CH}_{2} \mathrm{CMe}_{2} \mathrm{O}\right), 1.24$ (br s, $18 \mathrm{H}, \mathrm{CH}_{2} \mathrm{CMe}_{2} \mathrm{O}$ ), 0.97 (br s, 18H, CHMe $e_{2}$ ppm. ${ }^{13} \mathrm{C}$ NMR $\left(\mathrm{C}_{6} \mathrm{D}_{6}, 126 \mathrm{MHz}\right): 194.7$ (NCN), 130.29 (pyrrole $\mathrm{CH}$ ), 121.8 (NCHCHN), 119.8 (pyrrole $\mathrm{CH}$ ), 112.6 (NCHCHCN), 107.4 (pyrrole $\mathrm{CH}$ ), 104.19 (pyrrole $\mathrm{CH}), 72.0\left(\mathrm{CH}_{2} \mathrm{CMe}_{2} \mathrm{O}\right)$, $63.9\left(\mathrm{CH}_{2} \mathrm{CMe}_{2} \mathrm{O}\right), 50.2\left(\mathrm{HCMe}_{2}\right), 30.6\left(\mathrm{CH}_{2} \mathrm{CMe}_{2} \mathrm{O}\right), 23.4$ $\left(\mathrm{CHMe}_{2}\right)$ ppm. Yield: Quantitative by ${ }^{1} \mathrm{H}$ NMR spectroscopy. No microanalysis was determined due to loss of pyrrole on drying under vacuum.

\section{Reactivity of 4 towards pyrrole}

Neat pyrrole $(3.5 \mathrm{mg}, 0.05 \mathrm{mmol})$ was added to a solution of 4 $(0.05 \mathrm{~g}, 0.05 \mathrm{mmol})$ in $\mathrm{C}_{5} \mathrm{D}_{5} \mathrm{~N}$ in a Teflon-valved NMR tube, resulting in a pale orange solution. ${ }^{1} \mathrm{H}$ NMR $\left(500 \mathrm{MHz}, \mathrm{C}_{5} \mathrm{D}_{5} \mathrm{~N}\right.$,
$298 \mathrm{~K}$ ): $\delta 10.04$ (br. s, 1H), 7.48 (s, 2H), 7.09 (s, 8H), 6.67 (s, 2H), 5.75 (br. s, 4H), 3.98 (br. s, 8H), 1.37 (br. s, 24H), 1.16 (br. s, 24H) ppm.

In a similar manner, an excess of pyrrole $(0.05 \mathrm{~g}$, $0.75 \mathrm{mmol})$ was added to a solution of $4(0.02 \mathrm{~g}, 0.02 \mathrm{mmol})$ in $\mathrm{C}_{5} \mathrm{D}_{5} \mathrm{~N}$ in a Teflon-valved NMR tube, resulting in a pale orange solution. ${ }^{1} \mathrm{H}$ NMR $\left(500 \mathrm{MHz}, \mathrm{C}_{5} \mathrm{D}_{5} \mathrm{~N}, 298 \mathrm{~K}\right) \delta 11.23$ (s, $7 \mathrm{H}), 7.50(\mathrm{~s}, 1 \mathrm{H}), 7.46(\mathrm{~s}, 1 \mathrm{H}), 7.44(\mathrm{~s}, 1 \mathrm{H}), 7.41(\mathrm{~s}, 1 \mathrm{H}), 7.36(\mathrm{~s}$, $1 \mathrm{H}), 7.20(\mathrm{t}, J=1.9 \mathrm{~Hz}, 10 \mathrm{H}), 7.12(\mathrm{~s}, 1 \mathrm{H}), 6.61(\mathrm{~s}, 1 \mathrm{H}), 6.52$ $(\mathrm{t}, J=1.9 \mathrm{~Hz}, 10 \mathrm{H}), 6.39(\mathrm{~s}, 1 \mathrm{H}), 4.53(\mathrm{~s}, 1 \mathrm{H}), 4.45(\mathrm{~s}, 1 \mathrm{H}), 4.10$ $(\mathrm{s}, 2 \mathrm{H}), 4.07(\mathrm{~s}, 2 \mathrm{H}), 3.99(\mathrm{~s}, 4 \mathrm{H}), 1.41(\mathrm{~s}, 6 \mathrm{H}), 1.36(\mathrm{~s}, 21 \mathrm{H})$, $1.25(\mathrm{~s}, 12 \mathrm{H}) \mathrm{ppm}$.

8a - To a solution of freshly prepared 1-Ce $(0.30 \mathrm{~g}$, $0.66 \mathrm{mmol})$ in thf $(5 \mathrm{~mL})$ was added freshly distilled cyclopentadiene $(0.044 \mathrm{~g}, 0.66 \mathrm{mmol})$ and the resulting mixture was stirred at $60^{\circ} \mathrm{C}$ for $4 \mathrm{~h}$ during which time a colourless precipitate formed. The precipitate was collected by filtration, washed with hexanes $(3 \times 3 \mathrm{~mL})$ and dried under vacuum to afford $8 \mathbf{a}$ as a colourless material. Yield: $0.219 \mathrm{~g}$ (64\%). Diffractionquality crystals were grown from a concentrated thf solution. Poor solubility of the product prevented NMR analyses.

Anal. Found (Calcd for $\mathrm{C}_{25} \mathrm{H}_{33} \mathrm{~N}_{2} \mathrm{O}_{1} \mathrm{Ce}$ ): C, 57.58 (58.01), H, 6.01 (6.43), N, 5.53 (5.41).

9 - To a solution of freshly prepared $2-Y(0.30 \mathrm{~g}, 0.58 \mathrm{mmol})$ in thf $(5 \mathrm{~mL})$ was added freshly distilled cyclopentadiene $(0.039 \mathrm{~g}, 0.58 \mathrm{mmol})$ and the resulting mixture was stirred at $60{ }^{\circ} \mathrm{C}$ for $4 \mathrm{~h}$ during which time a colourless precipitate formed. The precipitate was collected by filtration, washed with hexanes $(3 \times 3 \mathrm{~mL})$ and dried under vacuum to afford 9 as colourless crystals. Yield: $0.256 \mathrm{~g}$ (68\%). Diffraction-quality crystals were grown from a concentrated thf solution. Poor solubility of the product prevented NMR analyses.

Anal. Found (Calcd for $\mathrm{C}_{35} \mathrm{H}_{51} \mathrm{~N}_{4} \mathrm{O}_{2} \mathrm{Y}$ ): C, 64.44 (64.80), H, 7.54 (7.92), N, 8.22 (8.64).

10 - To a solution of freshly prepared 1-Y $(0.20 \mathrm{~g}$, $0.50 \mathrm{mmol})$ in thf $(5 \mathrm{~mL})$ was added 1,1-diphenylacetone $(0.105 \mathrm{~g}, 0.5 \mathrm{mmol})$ and the resulting mixture was stirred at $60{ }^{\circ} \mathrm{C}$ for $1 \mathrm{~h}$, during which time a colourless precipitate formed. The precipitate was collected by filtration, washed with hexanes $(3 \times 3 \mathrm{~mL})$ and dried under vacuum to afford 10 as a colourless material. Yield: $0.192 \mathrm{~g}$ (63\%). Diffractionquality crystals were grown from a concentrated thf solution at room temperature.

${ }^{1} \mathrm{H}$ NMR (d ${ }^{8}$-thf, $\left.500 \mathrm{MHz}\right): 8.86(\mathrm{~s}, H \mathrm{CNN}), 7.48$ (d, ${ }^{3} \mathrm{~J}_{\mathrm{HH}}=$ $\left.7.4 \mathrm{~Hz}, 2 \mathrm{H},\left(\mathrm{C}_{6} \mathrm{H}_{5}\right)_{2} \mathrm{CCOMe}\right), 7.29$ (s, br, 1H, NCHCHN), $7.21(\mathrm{t}$, $\left.{ }^{3} J_{\mathrm{HH}}=7.6 \mathrm{~Hz}, 2 \mathrm{H}, \quad\left(\mathrm{C}_{6} \mathrm{H}_{5}\right)_{2} \mathrm{CCOMe}\right), 7.15-7.09(\mathrm{~m}, 3 \mathrm{H})$, $7.08-7.01(\mathrm{~m}, 3 \mathrm{H}), 6.78\left(\mathrm{t},{ }^{3} \mathrm{JHH}_{\mathrm{HH}}=7.3 \mathrm{~Hz}, 1 \mathrm{H},\left(\mathrm{C}_{6} \mathrm{H}_{5}\right)_{2} \mathrm{CCOMe}\right)$, $5.90\left(\mathrm{~s}, 10 \mathrm{H}, \mathrm{C}_{5} H_{5}\right), 4.56\left(\mathrm{sept},{ }^{3} \mathrm{~J}_{\mathrm{HH}}=6.7 \mathrm{~Hz}, 1 \mathrm{H}, \mathrm{CHMe}_{2}\right), 3.48$ (s, 2H, $\left.\mathrm{CH}_{2} \mathrm{CMe}_{2} \mathrm{O}\right), 1.98$ (s, 3H, $\left.\left(\mathrm{C}_{6} \mathrm{H}_{5}\right)_{2} \mathrm{CCOMe}\right), 1.51$ (d, $J=$ $\left.6.7 \mathrm{~Hz}, 6 \mathrm{H}, \mathrm{CHMe} e_{2}\right), 1.06$ (s, 6H, $\mathrm{CH}_{2} \mathrm{CMe}_{2} \mathrm{O}$ ); ${ }^{13} \mathrm{C} \mathrm{NMR}\left(\mathrm{d}^{8}\right.$-thf, $101 \mathrm{MHz}): 160.9$ (d, $\left.{ }^{2} J_{\mathrm{YC}}=3.3 \mathrm{~Hz},\left(\mathrm{C}_{6} \mathrm{H}_{5}\right)_{2} \mathrm{CCOMe}\right), 147.1(\mathrm{~s}$, ipso- $\left.\left(C_{6} \mathrm{H}_{5}\right)_{2} \mathrm{CCOMe}\right)$ ), 146.0 (s, ipso- $\left.\left(C_{6} \mathrm{H}_{5}\right)_{2} \mathrm{CCOMe}\right)$ ), 138.8 (s, $\mathrm{NCHN}$ ), 132.9 (s, $\left.\left(C_{6} \mathrm{H}_{5}\right)_{2} \mathrm{CCOMe}\right), 131.1$ (s, $\left.\left(C_{6} \mathrm{H}_{5}\right)_{2} \mathrm{CCOMe}\right)$, $128.5\left(\mathrm{~s},\left(C_{6} \mathrm{H}_{5}\right)_{2} \mathrm{CCOMe}\right), 128.0\left(\mathrm{~s},\left(C_{6} \mathrm{H}_{5}\right)_{2} \mathrm{CCOMe}\right), 125.1(\mathrm{~s}$, $\left.\left(C_{6} \mathrm{H}_{5}\right)_{2} \mathrm{CCOMe}\right), 124.5$ (s, NCHCHN), 123.5 (s, $\left.\left(C_{6} \mathrm{H}_{5}\right)_{2} \mathrm{CCOMe}\right)$, 117.7 (s, NCHCHN), $111.2\left(\mathrm{~s},\left(\mathrm{C}_{6} \mathrm{H}_{5}\right)_{2} C \mathrm{COMe}\right), 109.3\left(\mathrm{~s}, C_{5} \mathrm{H}_{5}\right)$ 
$72.7\left(\mathrm{~d}, J=5.7 \mathrm{~Hz}, C \mathrm{Me}_{2}\right), 63.2\left(\mathrm{~s}, \mathrm{OCMe}_{2} \mathrm{CH}_{2}\right), 53.5$ (s, $\mathrm{CHMe}_{2}$ ), 30.0 (s, $\mathrm{CH}_{2} \mathrm{CMe}{ }_{2} \mathrm{O}$ ), 26.0 (s, $\left.\left(\mathrm{C}_{6} \mathrm{H}_{5}\right)_{2} \mathrm{CCOMe}\right), 23.3$ (s, $\mathrm{CHMe}_{2}$ ) ppm; Anal. Found (Calcd for $\mathrm{C}_{35} \mathrm{H}_{41} \mathrm{~N}_{2} \mathrm{O}_{2} \mathrm{Y}$ ): C, 68.61 (68.84), H, 6.56 (6.77), N, 4.45 (4.59).

10a - An isomer of 10, labelled 10a can also be isolated from the room-temperature reaction between 1,1-diphenylacetone and 1-Y.

To a solution of freshly prepared $1-Y(0.20 \mathrm{~g}, 0.50 \mathrm{mmol})$ in thf $(5 \mathrm{~mL})$ was added 1,1-diphenylacetone $(0.105 \mathrm{~g}, 0.5 \mathrm{mmol})$ and the resulting mixture was stirred at room temperature for $1 \mathrm{~h}$. The resulting solution was cooled to $-30{ }^{\circ} \mathrm{C}$ upon which large colourless crystals formed. The crystals were collected by filtration, washed with hexanes $(3 \times 3 \mathrm{~mL})$ and dried under vacuum to afford 10a as a colourless material. Yield: $0.125 \mathrm{~g}$ (41\%). Crystals grown from a concentrated thf solution at $-30{ }^{\circ} \mathrm{C}$ were poorly diffracting. It should be noted that $10 \mathrm{a}$ can be converted quantitatively into $\mathbf{1 0}$ by heating a thf solution of 10a for $1 \mathrm{~h}$ at $60^{\circ} \mathrm{C}$.

${ }^{1} \mathrm{H}$ NMR (d ${ }^{8}$-thf, $\left.500 \mathrm{MHz}\right): 9.12(\mathrm{~s}, H \mathrm{CNN}), 7.44\left(\mathrm{~d},{ }^{3} \mathrm{~J}_{\mathrm{HH}}=\right.$ $\left.7.4 \mathrm{~Hz}, 2 \mathrm{H},\left(\mathrm{C}_{6} \mathrm{H}_{5}\right)_{2} \mathrm{CCOMe}\right), 7.31-7.17(\mathrm{~m}, 5 \mathrm{H}), 7.15-7.03$ $(\mathrm{m}, 5 \mathrm{H}), 5.78\left(\mathrm{~s}, 10 \mathrm{H}, \mathrm{C}_{5} H_{5}\right), 4.47\left(\mathrm{sept},{ }^{3} \mathrm{~J}_{\mathrm{HH}}=6.7 \mathrm{~Hz}, 1 \mathrm{H}\right.$, $\mathrm{CHMe}_{2}$ ), $3.56\left(\mathrm{~s}, 2 \mathrm{H}, \mathrm{CH}_{2} \mathrm{CMe}_{2} \mathrm{O}\right), 1.98\left(\mathrm{~s}, 3 \mathrm{H},\left(\mathrm{C}_{6} \mathrm{H}_{5}\right)_{2} \mathrm{CCOMe}\right)$, $1.43\left(\mathrm{~d}, J=6.7 \mathrm{~Hz}, 6 \mathrm{H}, \mathrm{CHMe}_{2}\right), 0.98$ (s, 6H, $\mathrm{CH}_{2} \mathrm{CMe}_{2} \mathrm{O}$ ); ${ }^{13} \mathrm{C}$ NMR (d ${ }^{8}$-thf, $\left.101 \mathrm{MHz}\right): 171.3\left(\mathrm{~d},{ }^{2} J_{\mathrm{YC}}=3.3 \mathrm{~Hz}\right.$, $\left(\mathrm{C}_{6} \mathrm{H}_{5}\right)_{2} \mathrm{CCOMe}$ ), 146.0 (s, ipso- $\left.\left(C_{6} \mathrm{H}_{5}\right)_{2} \mathrm{CCOMe}\right)$ ), 145.5 (s, ipso$\left.\left(C_{6} \mathrm{H}_{5}\right)_{2} \mathrm{CCOMe}\right)$ ), $138.2(\mathrm{~s}, \mathrm{NCHN}), 130.6$ (s, $\left.\left(C_{6} \mathrm{H}_{5}\right)_{2} \mathrm{CCOMe}\right)$, $128.6\left(\mathrm{~s},\left(C_{6} \mathrm{H}_{5}\right)_{2} \mathrm{CCOMe}\right), 128.0\left(\mathrm{~s},\left(C_{6} \mathrm{H}_{5}\right)_{2} \mathrm{CCOMe}\right), 126.5$ (s, $\left.\left(C_{6} \mathrm{H}_{5}\right)_{2} \mathrm{CCOMe}\right), 125.5$ (s, $\left.\left(C_{6} \mathrm{H}_{5}\right)_{2} \mathrm{CCOMe}\right), 125.2$ (s, NCHCHN), $124.5\left(\mathrm{~s}, \quad\left(C_{6} \mathrm{H}_{5}\right)_{2} \mathrm{CCOMe}\right), \quad 117.6 \quad(\mathrm{~s}, \quad \mathrm{NCHCHN}), \quad 109.4$ (s, $\left.\left(\mathrm{C}_{6} \mathrm{H}_{5}\right)_{2} C \mathrm{COMe}\right), 109.2\left(\mathrm{~s}, C_{5} \mathrm{H}_{5}\right) 71.8\left(\mathrm{~d}, J=5.7 \mathrm{~Hz}, C \mathrm{Me}_{2}\right)$, $63.8\left(\mathrm{~s}, \mathrm{OCMe}_{2} \mathrm{CH}_{2}\right), 53.4\left(\mathrm{~s}, \mathrm{CHMe}_{2}\right), 29.8\left(\mathrm{~s}, \mathrm{CH}_{2} \mathrm{CMe}_{2} \mathrm{O}\right), 26.0$ (s, $\left.\left(\mathrm{C}_{6} \mathrm{H}_{5}\right)_{2} \mathrm{CCOMe}\right), 23.3$ (s, $\left.\mathrm{CHMe} e_{2}\right) \mathrm{ppm}$.

\section{Acknowledgements}

The authors are grateful for the support of the Technische Universität München - Institute for Advanced Study, funded by the German Excellence Initiative, Sasol Technology, the University of Edinburgh, and the EPSRC.

\section{References}

1 X. Bugaut and F. Glorius, Chem. Soc. Rev., 2012, 41, 3511-3522.

2 V. Nair, S. Vellalath and B. P. Babu, Chem. Soc. Rev., 2008, 37, 2691-2698.

3 D. Enders, O. Niemeier and A. Henseler, Chem. Rev., 2007, 107, 5606-5655.

4 S. Gaillard, C. S. J. Cazin and S. P. Nolan, Acc. Chem. Res., 2012, 45, 778-787.

5 F. Glorius, $N$-Heterocyclic Carbenes in Transition Metal Catalysis, Springer, Berlin, 2007.

6 F. E. Hahn and M. C. Jahnke, Angew. Chem., Int. Ed., 2008, 47, 3122-3172.
7 H. Nakai, X. Hu, L. N. Zakharov, A. L. Rheingold and K. Meyer, Inorg. Chem., 2004, 43, 855-857.

8 P. L. Arnold and S. T. Liddle, Chem. Commun., 2006, 3959-3971.

9 T. Mehdoui, J. C. Berthet, P. Thuery and M. Ephritikhine, Chem. Commun., 2005, 2860-2862.

10 P. L. Arnold and I. J. Casely, Chem. Rev., 2009, 109, 35993611.

11 S. T. Liddle, I. S. Edworthy and P. L. Arnold, Chem. Soc. Rev., 2007, 1732-1744.

12 D. Enders, A. Grossmann, J. Fronert and G. Raabe, Chem. Commun., 2010, 46, 6282-6284.

13 Y. Shimakawa, T. Morikawa and S. Sakaguchi, Tetrahedron Lett., 2010, 51, 1786-1789.

14 D. A. DiRocco, K. M. Oberg, D. M. Dalton and T. Rovis, J. Am. Chem. Soc., 2009, 131, 10872-10874.

15 Q. Liu, S. Perreault and T. Rovis, J. Am. Chem. Soc., 2008, 130, 14066-14067.

16 R. Singh and S. P. Nolan, Chem. Commun., 2005, 54565458.

17 V. Nair, S. Bindu and V. Sreekumar, Angew. Chem., Int. Ed., 2004, 43, 5130-5135.

18 G. A. Grasa, T. Gueveli, R. Singh and S. P. Nolan, J. Org. Chem., 2003, 68, 2812-2819.

19 A. Grossmann and D. Enders, Angew. Chem., Int. Ed., 2012, 51, 314-325.

20 L. Candish and D. W. Lupton, Chem. Sci., 2012, 3, 380383.

21 T. Kano, K. Sasaki and K. Maruoka, Org. Lett., 2005, 7, 1347-1349.

22 S. Diez-Gonzalez, N. Marion and S. P. Nolan, Chem. Rev., 2009, 109, 3612-3676.

23 P. L. Watson and G. W. Parshall, Acc. Chem. Res., 1985, 18, 51-56.

24 B. A. Vastine and M. B. Hall, Coord. Chem. Rev., 2009, 253, 1202-1218.

25 W. J. Evans, Inorg. Chem., 2007, 46, 3435-3449.

26 T. E. Mueller, K. C. Hultzsch, M. Yus, F. Foubelo and M. Tada, Chem. Rev., 2008, 108, 3795-3892.

27 X. Yu, S. Seo and T. J. Marks, J. Am. Chem. Soc., 2007, 129, 7244-7245.

28 S. Hong and T. J. Marks, Acc. Chem. Res., 2004, 37, 673-686.

29 B. Liu and D. Cui, Dalton Trans., 2009, 550-556.

30 B. D. Stubbert and T. J. Marks, J. Am. Chem. Soc., 2007, 129, 4253-4271.

31 S. Seo, X. Yu and T. J. Marks, J. Am. Chem. Soc., 2009, 131, 263-276.

32 P. L. Arnold, I. A. Marr, S. Zlatogorsky, R. Bellabarba and R. P. Tooze, Dalton Trans., 2014, 43, 34-37.

33 P. L. Arnold, Z. R. Turner, A. I. Germeroth, I. J. Casely, G. S. Nichol, R. Bellabarba and R. P. Tooze, Dalton Trans., 2013, 42, 1333-1337.

34 Z. R. Turner, R. Bellabarba, R. P. Tooze and P. L. Arnold, J. Am. Chem. Soc., 2010, 132, 4050-4051.

35 P. L. Arnold, Z. R. Turner, R. Bellabarba and R. P. Tooze, J. Am. Chem. Soc., 2011, 133, 11744-11756. 
36 J. A. Joule and K. Mills, Heterocyclic Chemistry, Blackwell Science, Oxford, 4th edn, 2000.

37 M. Ganesan, M. P. Lalonde, S. Gambarotta and G. P. A. Yap, Organometallics, 2001, 20, 2443-2445.

38 P. L. Arnold, J. H. Farnaby, R. C. White, N. Kaltsoyannis, M. G. Gardiner and J. B. Love, Chem. Sci., 2014, 5, 756765.

39 J. W. Leeland, F. J. White and J. B. Love, Chem. Commun., 2011, 47, 4132-4134.

40 J. S. Hart, F. J. White and J. B. Love, Chem. Commun., 2011, 47, 5711-5713.

41 J. B. Love, Chem. Commun., 2009, 3154-3165.

42 S. Yang, X. Zhu, S. Zhou, S. Wang, Z. Feng, Y. Wei, H. Miao, L. Guo, F. Wang, G. Zhang, X. Gu and X. Mu, Dalton Trans., 2014, 43, 2521-2533.

43 X. Zhu, S. Zhou, S. Wang, Y. Wei, L. Zhang, F. Wang, S. Wang and Z. Feng, Chem. Commun., 2012, 48, 1202012022.

44 Y. Yang, Q. Wang and D. Cui, J. Polym. Sci., Part A: Polym. Chem., 2008, 46, 5251-5262.

45 P. L. Arnold, S. Zlatogorsky, N. A. Jones, C. D. Carmichael, S. T. Liddle, A. J. Blake and C. Wilson, Inorg. Chem., 2008, 47, 9042-9049.

46 B. L. Wang, D. Wang, D. M. Cui, W. Gao, T. Tang, X. S. Chen and X. B. Jing, Organometallics, 2007, 26, 31673172.

47 S. T. Liddle and P. L. Arnold, Organometallics, 2005, 24, 2597-2605.

48 I. J. Casely, S. T. Liddle, A. J. Blake, C. Wilson and P. L. Arnold, Chem. Commun., 2007, 5037-5039.

49 P. L. Arnold, A. J. Blake and C. Wilson, Chem. - Eur. J., 2005, 11, 6095-6099.
50 B. A. Belinka Jr., A. Hassner and J. M. Hendler, J. Org. Chem., 1981, 46, 631-632.

51 S. Arndt, A. Trifonov, T. P. Spaniol, J. Okuda, M. Kitamura and T. Takahashi, J. Organomet. Chem., 2002, 647, 158-166.

52 Q. F. Mokuolu, P. A. Duckmanton, P. B. Hitchcock, C. Wilson, A. J. Blake, L. Shukla and J. B. Love, Dalton Trans., 2004, 1960-1970.

53 F. G. Bordwell, G. E. Drucker, N. H. Andersen and A. D. Denniston, J. Am. Chem. Soc., 1986, 108, 7310-7313.

54 F. G. Bordwell, G. E. Drucker and H. E. Fried, J. Org. Chem., 1981, 46, 632-635.

55 U. Baisch, S. Pagano, M. Zeuner, J. Schmedt auf der Günne, O. Oeckler and W. Schnick, Organometallics, 2006, 25, 3027-3033.

56 A. R. Crozier, K. W. Törnroos, C. Maichle-Mössmer and R. Anwander, Eur. J. Inorg. Chem., 2013, 2013, 409-414.

57 P. Dröse, A. R. Crozier, S. Lashkari, J. Gottfriedsen, S. Blaurock, C. G. Hrib, C. Maichle-Mössmer, C. Schädle, R. Anwander and F. T. Edelmann, J. Am. Chem. Soc., 2010, 132, 14046-14047.

58 C. D. Abernethy, C. L. B. Macdonald, J. A. C. Clyburne and A. H. Cowley, Chem. Commun., 2001, 61-62.

59 C. D. Abernethy, J. A. C. Clyburne, A. H. Cowley and R. A. Jones, J. Am. Chem. Soc., 1999, 121, 2329-2330.

60 K. Biradha and M. J. Zaworotko, J. Am. Chem. Soc., 1998, 120, 6431-6432.

61 S. Gambarotta, S. Strologo, C. Floriani, A. Chiesi-Villa and C. Guastini, Inorg. Chem., 1985, 24, 654-660.

62 J. M. Birmingham and G. Wilkinson, J. Am. Chem. Soc., 1956, 78, 42-44.

63 P. L. Arnold, M. Rodden and C. Wilson, Chem. Commun., 2005, 1743-1745. 